University at Buffalo School of Law

Digital Commons @ University at Buffalo School of Law

1992

\title{
The Failed Discourse of State Constitutionalism
}

James A. Gardner

University at Buffalo School of Law

Follow this and additional works at: https://digitalcommons.law.buffalo.edu/journal_articles

Part of the Constitutional Law Commons, and the State and Local Government Law Commons

\section{Recommended Citation}

James A. Gardner, The Failed Discourse of State Constitutionalism, 90 Mich. L. Rev. 761 (1992).

Available at: https://digitalcommons.law.buffalo.edu/journal_articles/218

\section{C) ${ }_{\text {COPYRIGHT }}^{\text {N }}$}

This Article is brought to you for free and open access by the Faculty Scholarship at Digital Commons @ University at Buffalo School of Law. It has been accepted for inclusion in Journal Articles by an authorized administrator of Digital Commons @ University at Buffalo School of Law. For more information, please contact lawscholar@buffalo.edu. 


\title{
THE FAILED DISCOURSE OF STATE CONSTITUTIONALISM
}

\author{
James A. Gardner* \\ TABle of Contents
}

INTRODUCTION $\ldots \ldots \ldots \ldots \ldots \ldots \ldots \ldots \ldots \ldots \ldots \ldots \ldots \ldots \ldots, 762$

I. Constitutional Discourse $\ldots \ldots \ldots \ldots \ldots \ldots \ldots \ldots, 767$

A. Definition ........................... 767

B. The Significance of Constitutional Discourse........ 768

C. Federal Constitutional Discourse as a Model ....... 770

II. New Federalism ....................... 771

III. The Poverty of State Constitutional

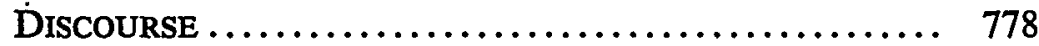

A. General Trends........................ 780

1. The Infrequency of State Constitutional

Decisions .......................... 780

2. Grudging Resort to the State Constitution ...... 781

3. Obscurity Concerning the Basis of Rulings...... 785

4. Lockstep Analysis ...................... 788

5. Silence on State Constitutional History ........ 793

B. Exceptions............................. 794

1. Divergences from Federal Law ............. 795

2. Independent Analysis .................... 799

3. The California Caseload ................... 800

4. New Hampshire........................ 801

C. Conclusions ........................... 804

IV. The Standard ExPlanations $\ldots \ldots \ldots \ldots \ldots \ldots \ldots \ldots . \ldots 05$

A. The Fourteenth Amendment ............... 805

B. Lawyers and Law Schools ................... 810

C. Lack of Historical Data ..................... 811

V. The Failure of State Constitutionalism........ 812

A. State Constitutionalism .................. 812

1. Federalism......................... 812

(C) Copyright 1991 by James A. Gardner.

* Associate Professor of Law, Western New England College School of Law. B.A. 1980, Yale University; J.D. 1984, University of Chicago. - Ed. I wish to thank Lise Gelernter, Leora Harpaz, Don Korobkin, Jay Mootz, and James Boyd White for commenting on previous drafts. Thanks are also due to Western New England College School of Law and Dean Howard Kalodner for providing financial support and to Stephanie Lebowitz for providing research assistance. 
2. Constitutionalism ..................... 814

3. Constitutionalism and Constitutional Discourse .. 815

4. Local Variations in Character ............... 816

B. Conundrums of Character.................. 818

C. The Incompatibility of State and Federal

Constitutionalism ........................ 823

1. The Framework of Nationhood ............. 823

2. The Dangers of a Robust State

Constitutionalism ...................... 826

3. The National Focus on Fundamental Values .... 827

D. The Nature of State Constitutional Differences ..... 830

VI. Some Possible Resolutions .................. 832

ConcLusion ................................. 836

\section{INTRODUCTION}

Fifteen years ago, Justice William Brennan wrote an article in which he called upon state courts to "step into the breach" left by what Brennan perceived to be the U.S. Supreme Court's retreat from its commitment to the protection of individual rights. ${ }^{1}$ Brennan urged state supreme courts to seize control of the protection of constitutional rights by looking to state constitutions as potentially more generous guarantors of individual rights than the U.S. Constitution as construed by the Burger Court. Brennan's article, which has been called the "Magna Carta" of state constitutionalism,2 earned him the sobriquet of "patron saint" of state constitutional law ${ }^{3}$ and gave birth to a movement advocating state independence in constitutional decisionmaking. Adherents of this "New Federalism" movement," who include among their number several distinguished state jurists ${ }^{5}$ and some prolific aca-

1. William J. Brennan, Jr., State Constitutions and the Protection of Individual Rights, 90 HARV. L. REv. 489, 503 (1977) [hereinafter Brennan, State Constitutions]; see also William J. Brennan, Jr., The Bill of Rights and the States: The Revival of State Constitutions as Guardians of Individual Rights, 61 N.Y.U. L. REV. 535 (1986) [hereinafter Brennan, Bill of Rights].

2. Stewart G. Pollock, State Constitutions as Separate Sources of Fundamental Rights, 35 RUTGERS L. REV. 707, 716 (1983).

3. Earl M. Maltz, False Prophet - Justice Brennan and the Theory of State Constitutional Law, 15 HASTINGS CONST. L.Q. 429, 429 (1988).

4. The movement has also been called the "New Judicial Federalism" to distinguish it from a legislative program pushed during the Reagan Administration that was also called "New Federalism." The Reagan Administration program involved making changes in federal law designed to reallocate governmental responsibilities from the federal to state governments. The New Federalism under discussion here is a state-initiated movement to achieve judicial rather than legislative independence from the federal government, and on a constitutional rather than programmatic level.

5. Former Oregon Supreme Court Justice Hans Linde, Wisconsin Supreme Court Justice Shirley Abrahamson, New Jersey Supreme Court Justice Stewart Pollock, New York Court of Appeals Judge Judith Kaye, and Washington Supreme Court Justice Robert Utter have been 
demics, ${ }^{6}$ have produced a voluminous body of commentary studying the decisions of state supreme courts, and exhorting them to greater decisional independence. ${ }^{7}$ Judging from this literature, the advocates of New Federalism are extraordinarily optimistic about the prospects for state constitutional law achieving the independence and prominence necessary not only to meet Justice Brennan's challenge, but to fulfill what they regard as the promise of a genuinely federal system of government. 8

The recent retirement of Justices Brennan and Thurgood Marshall, the last two liberals on the U.S. Supreme Court, ${ }^{9}$ and the corresponding solidification during the 1990-1991 Term of the Court's conservative majority, make this an appropriate time to reconsider the potential role of state constitutional law in American society. Are state courts, as proponents of New Federalism contend, developing an independent body of constitutional jurisprudence? If so, will state courts assume the dominant role traditionally occupied by the Supreme Court in articulating and protecting individual rights? If not, can they assume such a role, and should they?

In this article, I approach these questions in two steps. First, I examine the status of state constitutional law as it is practiced today. I conclude that, contrary to the claims of New Federalism, state constitutional law today is a vast wasteland of confusing, conflicting, and essentially unintelligible pronouncements. I argue that the fundamental defect responsible for this state of affairs is the failure of state

among the most active contributors to the New Federalism literature. See, e.g., Shirley S. Abrahamson, Criminal Law and State Constitutions: The Emergence of State Constitutional Law, 63 TeXas L. Rev. 1141 (1985); Judith S. Kaye, Dual Constitutionalism in Practice and Principle, 61 ST. JohN's L. REv. 399 (1987); Hans A. Linde, E Pluribus - Constitutional Theory and State Courts, 18 GA. L. Rev. 165 (1984); Pollock, supra note 2; Robert F. Utter, State Constitutional Law, the United States Supreme Court, and Democratic Accountability: Is There a Crocodile in the Bathtub?, 64 WASH. L. REv. 19 (1989).

6. Ronald K.L. Collins, Robert F. Williams, and Donald E. Wilkes, Jr. have been among the more active expounders of New Federalism. Representative examples of their work include Ronald K.L. Collins, Reliance on State Constitutions - The Montana Disaster, 63 TEXas L. Rev. 1095 (1985); Donald E. Wilkes, Jr., First Things Last: Amendomania and State Bills of Rights, 54 Miss. L.J. 223 (1984); Robert F. Williams, In the Supreme Court's Shadow: Legitimacy of State Rejection of Supreme Court Reasoning and Result, 35 S.C. L. REv. 353 (1984).

7. For comprehensive bibliographies of the literature, both old and new, dealing with state constitutional law, see Developments in STATE Constitutional LAW 317-35 (Bradley D. McGraw ed., 1985); Tim J. Watts, State Constitutional Law Development: A BibliOGRAPHY (1991); Earl M. Maltz et al., Selected Bibliography on State Constitutional Law, 20 RUTGERS L.J. 1093 (1989).

8. See infra notes $37-38$ and accompanying text.

9. Justice Blackmun is today often considered a liberal. This shows how times have changed. During his early years on the Court he was considered a centrist, if not a conservative. See Philip B. Kurland, 1970 Term: Notes on the Emergence of the Burger Court, 1971 SUP. CT. REv. 265, 268. 
courts to develop a coherent discourse of state constitutional law that is, a language in which it is possible for participants in the legal system to make intelligible claims about the meaning of state constitutions.

Second, I analyze the reasons for the failure of state courts to develop such a discourse. After rejecting several frequently offered explanations, I conclude that the failure of state constitutional discourse reflects a much deeper failure, a failure of state constitutionalism itself. The central premise of state constitutionalism is that a state constitution reflects the fundamental values, and ultimately the character, of the people of the state that adopted it. This premise, however, cannot serve as the foundation for a workable state constitutional discourse because it is not a good description of actual state constitutions; it embraces theoretical inconsistencies that undermine its value as a framework for a coherent discourse; and it takes an obsolete and potentially dangerous view of the texture and focus of American national identity.

Before turning to the analysis itself, I want to convey a better sense of the problem I will be addressing by relating a story of sorts about state constitutional law. It is a story that I believe describes the experience of a great many lawyers in this country.

Imagine that you are researching potential challenges that your client could make to a state law. You research federal constitutional law and find that you have a potential argument under, let us say, the Equal Protection Clause. But you soon find that the standard applied by the federal courts - suppose rational basis review applies - is so deferential that your federal claim is a guaranteed loser. Good lawyer that you are, though, you recall that your state constitution also contains an equal protection clause. Perhaps, you think to yourself, the state constitution offers more favorable possibilities for your client.

You now begin to research state constitutional law. What do you find? One distinct possibility is that the state courts have held that the state provision means exactly the same thing as the federal provision, and that whatever analysis the federal courts use under the federal Constitution is the analysis that should be used under the state constitution as well. ${ }^{10}$ This result is unsatisfying, but at least it ends your research. After confirming your conclusion, you abandon further state constitutional research as unproductive - it adds nothing to your case. If you mention the state constitution at all, it might be a pro 
forma citation just to remind the court of the dual nature of your claim.

Now suppose you are luckier, and find that the state provision either has never been construed, ${ }^{11}$ or that the state supreme court has held that the meaning of the state constitutional provision is not dependent on the meaning of the federal one. Perhaps you even find a handful of cases in which the state courts have rejected the analogous federal analyses and have reached results different from those that federal courts would reach. ${ }^{12}$ Your heart is filled with hope. Although you will not find your argument handed to you on a silver platter, you at least have an opening, it seems, to craft an argument that the state constitutional provision has a meaning more favorable to your client than its federal counterpart.

You now get down to serious work. After all, you know how to "do" constitutional law. You will comb the state decisions to unearth the relevant history of the provision at issue. You will figure out which framers of the state constitution the state supreme court considers influential, and you will discover useful tidbits concerning their constitutional philosophy. You will ferret out from state supreme court decisions broad language about the history, purpose, structure, and political theory of the state constitution. You will then weave these materials together into a coherent and convincing story about the state constitution, perhaps contrasting it with the familiar stories of the federal Constitution. This story will form the basis for your state constitutional claim on behalf of your client.

When you undertake this research, here is what you are likely to find. After reading dozens of state constitutional decisions, you have absolutely no sense of the history of the state constitution. You do not know the identity of the founders, their purposes in creating the constitution, or the specific events that may have shaped their thinking. You find nothing in the decisions indicating how the various provisions of the document fit together into a coherent whole, and if you do find anything at all it is a handful of quotations from federal cases discussing the federal Constitution. You are able to form no conception of the character or fundamental values of the people of the state, and no idea how to mount an argument that certain things are more important to the people than others. If you have found state court decisions departing from the federal approach to the corresponding federal provision, you have no idea why the courts departed from fed-

11. State constitutions are often less thoroughly elaborated than the federal Constitution. See infra note 69.

12. See infra notes 141-61 and accompanying text. 
eral reasoning; at best, you are left with the vague impression that the courts simply thought the dissents in analogous federal cases more persuasive. But nothing in these state opinions gives you any idea of what you, as an advocate, could say to convince the state courts once again to reject the federal approach as a matter of state constitutional law.

As a result of this uncertainty, you are unable to draft an argument in which you have the slightest confidence, and you end up throwing anything you can think of at the court and praying that something hits the mark. If you are really dispirited, you may decide to abandon the state constitutional claim entirely, concluding that your client's money is better spent on trying to develop a novel federal constitutional argument; at least you will have some chance of evaluating the merits of such an argument, whereas you have virtually no idea what will succeed or fail in state court.

This story illustrates what I call the poverty of state constitutional discourse, by which I mean the lack of a language in which participants in the legal system can debate the meaning of the state constitution. Further, to the extent that such a state constitutional discourse exists, its terms and conventions are often borrowed wholesale from federal constitutional discourse, as though the language of federal constitutional law were some sort of lingua franca of constitutional argument generally. My aim in this article is to demonstrate more formally the poverty of state constitutional discourse and to offer an explanation for this state of affairs.

Specifically, Part I describes in more detail the concept of a state constitutional discourse. Part II examines the New Federalism movement and its claims concerning the maturation of state constitutional law. In Part III, I summarize the results of a survey of over 1200 cases decided by state supreme courts during 1990 to document my claim that state constitutional discourse is impoverished and inadequate to the tasks that any constitutional discourse is designed to accomplish. Part IV discusses and rejects three common explanations for the poverty of state constitutional discourse. In Part V, I argue that the real reason for the failure of state constitutional discourse is the failure of state constitutionalism itself, which is internally inconsistent and relies on inadequate and outdated assumptions concerning the nature of state and national identity. As a result, state courts do not talk in the way state constitutionalism predicts because to do so would be to talk in a way that makes no sense. Part VI explores some possible resolutions of this dilemma. 


\section{Constitutional Discourse}

\section{A. Definition}

In the analysis that follows, I use the term constitutional discourse in a very specific sense. By constitutional discourse, I mean a language and set of conventions that allow a participant in the legal system to make an intelligible claim about the meaning of the constitution. This definition is dense, so I will break it down somewhat. First, by "participant in the legal system," I mean primarily lawyers, judges, and litigants - the people who carry on the daily business of adjudicating actual controversies within the legal system. ${ }^{13}$ Second, by "claim about the meaning of the constitution," I mean simply any statement to the effect that the relevant constitution, or any of its provisions, has a certain meaning. Examples of such claims might include the following: "The constitution embodies our society's commitment to the treatment of all citizens with equal dignity"; or "The Fourth Amendment prohibits police officers from frisking an individual without some reason to suspect that the individual may be armed"; or "Constitutional due process does not require the legislature to deal with every aspect of an economic problem at once."

By "intelligible claim," I mean a claim about the meaning of the constitution that is (1) acknowledged by other participants in the legal system to be a proper way of talking about the meaning of the constitution, and (2) capable of being understood by them, and therefore capable of being the subject of further constitutional discourse. These are simply the conditions necessary for any sort of meaningful conversation to take place. ${ }^{14}$ With respect to a constitution, a claim must be intelligible if it is to be disputed by opposing counsel or adjudicated by a judge. In our legal system, for example, a claim about the meaning of the Constitution based on astrological portents would be considered unintelligible under this definition because astrological arguments are not acknowledged to be a proper way of talking about constitutions. ${ }^{15}$

13. Much legal discourse incorporates the convenient fiction that only litigants make legal claims and arguments, and that their lawyers never do ("plaintiff argues," "defendant contends," and so on). Whether the litigant or the lawyer is considered the "real" participant in the legal system is immaterial to my analysis, although I expect that my analysis would be of interest primarily to lawyers, since they usually craft the arguments that form the actual raw material on which the legal system acts.

14. See, e.g. JAMES B. White, Heracles' Bow 33 (1985) [hereinafter White, Heracles]; James B. White, Justice as Translation 23 (1990) [hereinafter White, Translation]; Richard H. Fallon, Jr., A Constructivist Coherence Theory of Constitutional Interpretation, 100 HARV. L. REV. 1189, 1233 (1987).

15. Cf. Philip Bobbitt, Constitutional Fate 6 (1982) ("[O]vert religious arguments or appeals to let the matter be decided by chance or by reading entrails . . . are not part of our legal grammar."). 
Finally, when I refer to "federal constitutional discourse" and "state constitutional discourse," I refer to a language and set of conventions that allow participants in the legal system to make intelligible claims about the federal and state constitutions, respectively. ${ }^{16}$

This definition of constitutional discourse is at the same time narrow and broad. It is narrow in that it excludes talk about a constitution that takes place outside the legal system. Those who analyze constitutions in their sociological, political, or historical contexts doubtless engage in a useful sort of constitutional discourse, but it is a sort of discourse I shall not be concerned with here except to the extent that such analyses are or can be used within the legal system to support legal claims about the meaning of the Constitution. ${ }^{17}$

On the other hand, the definition is broad in that it includes anything at all that the participants in the legal system consider an appropriate argument about constitutional meaning. While some have argued that legitimate constitutional discourse should be confined to certain types of arguments - for example, arguments about the constitutional text and intent of the Framers ${ }^{18}$ - I include here any type of argument widely made and accepted. Thus, if astrological or theological arguments were deemed by participants in the legal system to be appropriate bases for adjudicating constitutional claims, they would fall within the definition of constitutional discourse used here.

\section{B. The Significance of Constitutional Discourse}

Before going any further, it seems appropriate to ask: Why does constitutional discourse, thus defined, matter? Constitutional discourse matters very much, for several reasons. First, it is the means by which authoritative interpretations of constitutions are produced. In our system of government, not all expressions of opinion about constitutions are equal; courts have the final say, ${ }^{19}$ and, at least with respect to constitutional issues that come before them, the only say that is authoritative in terms of guiding real exercises of real governmental power. Because courts are passive in our system, responding only to

16. Because federal constitutional claims can be raised in state courts, Martin v. Hunter's Lessee, 14 U.S. (1 Wheat.) 304 (1816), and state constitutional claims can be raised in certain federal court cases, Erie R.R. v. Tompkins, 304 U.S. 64 (1938), I do not distinguish here between participants in the federal legal system and participants in state legal systems.

17. For examples of studies of the role played by the U.S. Constitution in nonlegal public life, see Michael Kammen, A Machine That Would Go of ItSelf (1986) [hereinafter KaMMEN, Machine]; Michael Kammen, Sovereignty and Liberty: Constitutional DisCOURSE IN AMERICAN CULTURE (1988).

18. See Daniel A. Farber, The Originalism Debate: A Guide for the Perplexed, 49 Оно ST. L.J. 1085 (1989).

19. Cooper v. Aaron, 358 U.S. 1, 18 (1958). 
requests for judicial action, constitutional discourse is generally the only means by which positive constitutional law is made, other than by adopting or amending a constitution. In this sense, constitutional discourse gives legal life to the constitution within the legal system of which the constitution is a part.

But constitutional discourse is more than a mechanical procedure for producing the authoritative interpretations of the constitution needed to effectuate constitutional government. It is also the means by which participants in the legal system debate among themselves the meaning of the document. One side makes a claim about the meaning of the constitution; the other side responds by disputing that claim and making its own different one, which the first side disputes. The court then jumps into the exchange, questioning, accepting, rejecting, or modifying the claims made by the parties and reaching a conclusion. This debate among the participants plays a significant role in shaping the authoritative constitutional pronouncements the judicial system ultimately yields.

That constitutional discourse comprises a debate about the meaning of the constitution has important implications for a society that conceives of itself as living under that constitution. For what do we debate when we debate the meaning of a constitution? It has often been observed that any discourse is in a sense a means of self-definition, both for the individuals who engage in the discourse and the community of individuals among whom the discourse takes place. ${ }^{20}$ As Richard Sherwin has argued, "it is through discourse itself that who we are and the community and culture we belong to take on an embodied existence in the world."21 Thus, virtually any type of discourse is a means of debating the identity - the internal roles, relations, and ethos - of the community in which it occurs. ${ }^{22}$

But if this is true of discourse generally, it seems especially true of constitutional discourse because a constitution is a document that selfconsciously defines a communal identity. In Part V, I discuss the nature of constitutions and American constitutionalism in some detail. For now, it is sufficient to say that a constitution, according to our legal and social conventions, is a document meant to identify a polit-

20. See, e.g., WhITE, TRANSLATION, supra note 14, at ix, 23, 217; WHITE, HeRACLES, supra note 14, at 34, 80, 169; Richard Delgado, Storytelling for Oppositionists and Others: $A$ Plea for Narrative, 87 Mrch. L. REv. 2411, 2412 (1989); Paul W. Kahn, Community in Contemporary Constitutional Theory, 99 YALE L.J. 1, 5 (1989).

21. Richard K. Sherwin, A Matter of Voice and Plot: Belief and Suspicion in Legal Storytelling, 87 MICH. L. REV. 543, 564 (1988).

22. White, Heracles, supra note 14 , at $34,96,98$; White, Translation, supra note 14 , at 215-17. 
ical community and to set out some of the most fundamental principles according to which the members of the community wish to live their lives. Consequently, to debate the meaning of a constitution, as participants in the legal system do when they engage in constitutional discourse, is to debate some aspect of the most fundamental characteristics of the constitutional community's understanding of its own identity. It is to claim that we are (or are not) a certain type of people, who hold dear certain values and not others, and who act in certain ways in particular situations.

Thus, constitutional discourse is an integral aspect not only of constitutional law as a body of positive legal authority, but of societal selfidentification as well. As a result, to monitor a society's constitutional discourse is in an important sense to take the pulse of that society's efforts to understand itself.

\section{Federal Constitutional Discourse as a Model}

My purpose in Part III is to describe and criticize state constitutional discourse as it is currently practiced. In particular, I shall argue that state constitutional discourse is "impoverished." In order to get a better sense of what this conclusion entails, we may usefully contrast state constitutional discourse with its far more successful cousin, American federal constitutional discourse.

Our federal constitutional discourse is extraordinarily rich. Perhaps as a result of the age or stability of the U.S. Constitution, a participant in the legal system can today make claims about the meaning of the Constitution in a variety of ways. Among the types of arguments about the meaning of the Constitution widely acknowledged to be appropriate are arguments from the language and structure of the constitutional text; from history and the intent of the Framers; from constitutional theory; from judicial precedent and legal doctrine; and from a virtually limitless number of value systems dealing with matters such as ethics, justice, and social policy. ${ }^{23}$ This is more than enough raw material to allow a wide variety of disparate claims about the meaning of the Constitution, including claims that some otherwise active participants in the discourse may well consider outlandish. Indeed, some critics of federal constitutional jurisprudence, most prominently originalists, have argued that federal constitutional discourse is too rich - that too many types of arguments have been incorporated into the discourse, and that some of them do not furnish a 
legitimate language in which to make claims about the meaning of the Constitution. ${ }^{24}$

There is another reason for choosing federal constitutional discourse as a model of a successful constitutional discourse: it is the model adopted by the New Federalism movement as the one toward which state constitutional discourse should aspire.

\section{NeW FEDERALISM}

Today's New Federalism movement has its roots in two phenomena. The first is the liberal reaction in the mid-1970s to the jurisprudence of the Burger Court. As the Burger Court slowed the expansion of constitutionally protected individual rights begun by the Warren Court, many liberals began to look to state courts to take up the Warren Court's legacy in the form of rights-protective state constitutional rulings. ${ }^{25}$ The second phenomenon is a much older and sparser tradition of criticizing state courts for ignoring state constitutions as a source of law and for failing to develop vigorous and independent bodies of state constitutional law irrespective of the character of the constitutional jurisprudence of the U.S. Supreme Court. ${ }^{26}$ This strand of thought is often marked by criticism of state constitutions as well, often on the ground that state constitutions are poorly thought out or insufficiently "constitutional" in outlook. ${ }^{27}$

The marriage of these two schools gave birth to a New Federalism movement whose adherents, although occasionally impelled by different motives, ${ }^{28}$ shared the ultimate goal of creating in every state a vigorous, independent body of state constitutional law capable of

24. For an overview of originalism, see Farber, supra note 18.

25. See Project Report: Toward an Activist Role for State Bills of Rights, 8 HARv. C.R.-C.L. L. Rev. 271 (1973) [hereinafter Project Report ]; Brennan, State Constitutions, supra note 1; Jerome B. Falk, Jr., The State Constitution: A More Than "Adequate" Nonfederal Ground, 61 CAL. L. REv. 273 (1973); A.E. Dick Howard, State Courts and Constitutional Rights in the Day of the Burger Court, 62 VA. L. REv. 873 (1976); see also Ronald K.L. Collins, Reliance on State Constitutions - Away From a Reactionary Approach, 9 HASTINGs CoNsT. L.Q. 1 (1981); Sanford Levinson, Freedom of Speech and the Right of Access to Private Property Under State Constitutional Law, in Developments in State Constitutional Law, supra note 7, at 51.

26. See Scott H. Bice, Anderson and the Adequate State Ground, 45 S. CAL. L. REv. 750 (1972); Hans A. Linde, Without "Due Process": Unconstitutional Law in Oregon, 49 OR. L. REv. 125 (1970); William F. Swindler, State Constitutions for the 20th Century, 50 NEB. L. REv. 577, 583-89 (1971); Orrin K. McMurray, Note, Some Tendencies in Constitution Making, 2 CAL. L. REv. 203, 220-24 (1914); Note, California's Constitutional Amendomania, 1 STAN. L. REv. 279, 280-81 (1949) [hereinafter Note, Amendomania]; see generally Charles R. Adrian, Trends in State Constitutions, 5 HARV. J. ON LEGIS. 311 (1968).

27. See, e.g., Swindler, supra note 26, at 590, 593; McMurray, supra note 26, at 207, 210; Note, Amendomania, supra note 26, at 279-80.

28. Peter R. Teachout, Against the Stream: An Introduction to the Vermont Law Review Symposium on the Revolution in State Constitutional Law, 13 VT. L. REV. 13, 34-35 (1988). 
standing by itself as a basis for constitutional rulings by state courts. Both groups also shared the belief that state constitutional law was not living up to its potential as a source of independent law. Much of the early literature was therefore devoted to criticizing state court decisions for what New Federalism advocates saw as sloppy or inappropriate constitutional decisionmaking practices. These practices included avoiding reliance on state constitutions altogether; ${ }^{29}$ analyzing state constitutions in a perfunctory manner that provided little guidance to litigants and lower courts; ${ }^{30}$ and inappropriately relying on federal rulings and analyses as a guide to construction of state constitutions. ${ }^{31}$

As New Federalism matured, its adherents began increasingly to take the view that state constitutional jurisprudence should be something more than a vehicle for relitigating civil rights battles lost in the federal courts. Although some critics have argued that virtually all New Federalism proponents are motivated by the bare desire to achieve a liberal political agenda, ${ }^{32}$ it seems clear that an overwhelming consensus has developed within the movement that "reactive" state constitutional jurisprudence - state rulings that reject federal constitutional decisions merely because the state court disagrees with the result - is generally inappropriate. ${ }^{33}$ Rather, state constitutional

29. E.g., Shirley S. Abrahamson, Reincarnation of State Courts, 36 Sw. L.J. 951, 957-58 (1982) (observing that most state courts failed to look to state constitutions); Abrahamson, supra note 5, at 1147 (noting that state courts fell silent in this area from the late 1950s through the 1970s); Charles G. Douglas, III, State Judicial Activism - The New Role for State Bills of Rights, 12 SUFFolk L. REv. 1123, 1144 (1978) (state constitutions "moribund"); Stanley Mosk, State Constitutionalism After Warren: Avoiding the Potomac's Ebb and Flow, in DEVELOPMENTS IN STATE CONSTITUTIONAL LAW, supra note 7, at 201 ("[S]tate courts were guilty of a dismal performance in enforcing provisions of their own constitutions."); Ellen A. Peters, State Constitutional Law: Federalism in the Common Law Tradition, 84 MiCH. L. Rev. 583, 587 (1986) (State constitutional law suffered "generations of neglect - for which state courts bear a great deal of responsibility."); Ronald K.L. Collins, Reliance on State Constitutions: Some Random Thoughts, in Developments in STATE CONSTITUTIONal LAW, supra note 7, at 1, 4 (describing state constitutional law as "dormant").

30. Hans A. Linde, First Things First: Rediscovering the States' Bills of Rights, 9 U. BALT. L. REV. 379, 390 (1980).

31. Todd F. Simon, Independent But Inadequate: State Constitutions and Protection of Freedom of Expression, 33 KAN. L. REv. 305, 308 (1985); Developments in State Constitutional Law: 1989, 21 RUTGERS L.J. 903, 1111 (1990); see also Edmund B. Spaeth, Jr., Toward a New Partnership: The Future Relationship of Federal and State Constitutional Law, 49 U. PITT. L. REv. 729, 736-37 (1988).

32. E.g., Earl M. Maltz, The Political Dynamic of the "New Judicial Federalism," 2 EMERGING IsSUES IN ST. CONST. L. 233, 233 (1989).

33. E.g., Collins, supra note 25, at 2-3; Peter J. Galie, The Other Supreme Courts: Judicial Activism Among State Supreme Courts, 33 SYRACuSE L. REv. 731, 779, 786 (1982); Ken Gormley, Ten Adventures in State Constitutional Law, 1 EMERgING Issues IN ST. CoNST. L. 29, 35 (1988); A.E. Dick Howard, The Renaissance of State Constitutional Law, 1 EMERGING Issues IN ST. CoNST. L. 1, 12-13 (1988); Paul S. Hudnut, State Constitutions and Individual Rights: The Case for Judicial Restraint, 63 DENVER U. L. REV. 85, 95 (1985); Kaye, supra note 5, at 418; Robin B. Johansen, Note, The New Federalism: Toward a Principled Interpretation of the State Constitution, 29 STAN. L. REV. 297, 300 (1977). 
law must go its own way not in order to achieve a particular result, but because it is jurisprudentially an independent body of law.

New Federalism advocates support their arguments for state constitutional independence in several ways. Some claim a historical primacy for state constitutions. State constitutions, they argue, predated the federal Constitution and served in many respects as models consulted by the drafters of the federal Constitution and Bill of Rights. ${ }^{34}$ In addition, state constitutions were originally intended to be the primary vehicles for protecting the liberties of Americans, not the supplementary charters they have in many ways become. ${ }^{35}$ Others stress the many differences between the state and federal constitutions. They argue that a state constitution is a charter of government created by and for a different political sovereign; that it is a distinct document with a text that often differs significantly from its federal counterpart; and that state courts are institutions distinct from federal courts in both their authority and the circumstances under which that authority is exercised. ${ }^{36}$ These differences, it is argued, necessarily give rise to a distinct and independent body of law.

Finally, some argue that a vigorous and independent body of state constitutional law is not only contemplated, but virtually required, by the American system of federalism. In a federal system, the states are supposed to be counterweights to federal power, an arrangement designed to protect liberty. ${ }^{37} \mathrm{~A}$ strong, independent state constitutional jurisprudence is an important aspect of state power and independence, and thus a necessary condition of a healthy federalism. ${ }^{38}$

34. Norman Dorsen, State Constitutional Law: An Introductory Survey, 15 CoNN. L. REv. 99, 99-101 (1982); Linde, supra note 30, at 380-81; Wilkes, supra note 6, at 223-24; Ronald F. Williams, State Constitutional Law Processes, 24 WM. \& MARY L. Rev. 169, 175 (1983).

35. See Barron v. Baltimore, 32 U.S. (7 Pet.) 243, 247 (1833); Stewart G. Pollock, Adequate and Independent State Grounds as a Means of Balancing the Relationship Between State and Federal Courts, 63 TeXAs L. REv. 977,979 (1985); Robert F. Utter, Freedom and Diversity in a Federal System: Perspectives on State Constitutions and the Washington Declaration of Rights, in DEVELOPMENTS IN STATE CONSTITUTIONAL LAW, supra note 7, at 239, 239.

36. See Howard, supra note 25 , at $934-40$; Howard, supra note 33 , at 1, 8; Kaye, supra note 5, at 403; Linde, supra note 5, at 173, 181-83; Burt Neuborne, Foreword: State Constitutions and the Evolution of Positive Rights, 20 RUTGERS L.J. 881, 893-901 (1989); Lawrence Gene Sager, Foreword: State Constitutions and the Strategic Space Between the Norms and Rules of Constitutional Law, 63 TEXAS L. Rev. 959, 973-76 (1985); Utter, supra note 35, at 241-43; Williams, supra note 6 , at $355,397-404$.

37. The Federalist Nos. 45, 46 (James Madison).

38. See Collins, supra note 25, at 5-6; Shirley S. Abrahamson, Homegrown Justice: The State Constitutions, in DeVelopmenTs IN STATE CONSTITUTIONAL LAW, supra note 7, at 306, 314. For a different view, see Earl M. Maltz, Lockstep Analysis and the Concept of Federalism, 496 ANNAls AM. ACAD. PoL. \& SoC. SCI. 98 (1988); Maltz, supra note 3. It has also been suggested that the U.S. Constitution pursues federalism even more directly by giving states the power to create federal constitutional rights; this occurs because the content of the rights protected by the Ninth Amendment is dictated by the content of the rights protected by state constitutions. See Calvin R. Massey, The Anti-Federalist Ninth Amendment and Its Implications for State Constitu- 
As Justice Stanley Mosk of the California Supreme Court has observed, New Federalism thus offers something for both liberals and conservatives: it can offer liberals a continuation of the Warren Court's expansion of constitutional rights, while at the same time offering conservatives "the triumph of federalism."39

Although New Federalism proponents are basically united on the need for vigorous, independent state constitutional law, they divide over the issue of how such a body of law should be developed. A sizable majority seems to prefer what has come to be known as the "primacy" approach to state constitutional interpretation, 40 an approach usually identified with former Oregon Supreme Court Justice Hans Linde, who has been called the "intellectual godfather" of New Federalism. ${ }^{41}$ The primacy approach holds that state courts confronted with constitutional issues should look to the state constitution in the first instance and should interpret it in a principled way that takes account of the text, history, structure, and underlying values of the document. ${ }^{42}$ In other words, state courts should approach their state constitutions just as the U.S. Supreme Court would approach the federal Constitution - as a unique and highly significant document with a meaning that can and must be derived through independent analysis of the document itself.

In contrast, a minority of New Federalism proponents prefer the "interstitial" approach to state constitutional adjudication. ${ }^{43}$ This approach holds that state courts should look in the first instance to the federal Constitution where that document can provide a basis for decision. Only if federal constitutional law approves the challenged state action, or is ambiguous, should the state court then turn to the state

tional Law, 1990 Wrs. L. REv. 1229; Eric B. Schnurer, It Is a Constitution We Are Expanding: An Essay on Constitutional Past, Present, and Future, 1 EMERging Issues IN ST. Const. L. 135 (1988).

39. Stanley Mosk, State Constitutionalism: Both Liberal and Conservative, 63 TEXAS L. REV. 1081, 1081 (1985).

40. Among the many who have endorsed the primacy approach are Abrahamson, supra note 29, at 962-63; Douglas, supra note 29, at 1145-46; Falk, supra note 25, at 285-86; Project Report, supra note 25, at 289; Frank G. Mahady, Toward a Theory of State Constitutional Jurisprudence: A Judge's Thoughts, 13 VT. L. REv. 145, 146 (1988); Simon, supra note 31, at 316; Utter, supra note 35, at 247; Collins, supra note 29 , at 7-9.

41. Ronald K.I. Collins, Foreword: The Once "New Judicial Federalism" \& Its Critics, 64 WASH. L. REv. 5, 5 (1989) (quoting Jeffrey Toobin, Better Than Burger, NEw Republic, Mar. 4,1985 , at 10,11 ).

42. Linde, supra note 5, at 178-81; Linde, supra note 30, at 380, 392.

43. Developments in the Law: The Interpretation of State Constitutional Rights, 95 HARv. L. REv. 1324, 1330-31 (1982) [hereinafter Developments in the Law]; Hudnut, supra note 33, at 99100; see also Peters, supra note 29, at 589-92 (advocating flexible approach to state constitutional interpretation). 
constitution. ${ }^{44}$ According to Justice Stewart Pollock of the New Jersey Supreme Court, the most articulate defender of the interstitial approach, this method is preferable to the primacy approach because it acknowledges the U.S. Constitution as the basic protector of individual rights in our society. ${ }^{45}$ State constitutional law thus plays a more modest role than it would under the primacy approach. ${ }^{46}$ However, Justice Pollock has cautioned that in order to avoid a state constitutional jurisprudence that merely reacts to federal rulings, state courts must diverge from federal holdings and results only in accordance with appropriate objective criteria. ${ }^{47}$

In 1983, New Federalism received an unlikely boost from the U.S. Supreme Court. In Michigan v. Long, ${ }^{48}$ the Court reconsidered its prior rulings concerning the doctrine of adequate and independent state grounds. Under this doctrine, the Supreme Court will not review a state court decision that rests on state law grounds even if the state decision also rests on federal law grounds for which a federal appeal normally would be available. ${ }^{49}$ The Court had reasoned that because state law is unreviewable by federal courts, a Supreme Court decision on the federal issue could not affect the outcome of the case and would therefore be an advisory opinion beyond the Court's Article III jurisdiction. ${ }^{50}$ In Long, the Court held that it would henceforth consider a state court decision to rest on adequate and independent state grounds only if it "indicates clearly and expressly that it is alternatively based on bona fide, separate, adequate, and independent grounds." 51 Thus, the Court now requires state courts to say explicitly when their deci-

44. Pollock, supra note 2, at 718; see also Developments in the Law, supra note 43 , at 1356-66 (discussing application of the interstitial model).

45. Pollock, supra note 2, at 718.

46. See Developments in the Law, supra note 43, at 1358 ("The state court's role is not to construct a complete system of fundamental rights from the ground up.").

47. Pollock, supra note 2, at 718; see also State v. Hunt, 450 A.2d 952, 965-67 (N.J. 1982) (Handler, J., concurring) (suggesting seven criteria for determining when the court should diverge from federal constitutional law).

A third approach has been identified in which state courts resolve all parallel state and federal constitutional claims regardless of the outcome of either analysis; that is, the court will not stop its analysis after turning to one constitution or the other, even if that analysis provides a definitive resolution to the case. This approach has been accurately criticized for creating an unreviewable state body of federal constitutional dicta. Bice, supra note 26; Pollock, supra note 35, at 983. But see Robert F. Utter, Swimming in the Jaws of the Crocodile: State Court Comment on Federal Constitutional Issues When Disposing of Cases on State Constitutional Grounds, 63 TEXAS L. REv. 1025, 1029-41 (1985) (arguing that this approach allows state courts to contribute to the development of federal constitutional law).

48. 463 U.S. 1032 (1983).

49. 463 U.S. at 1038-42.

50. 463 U.S. at 1040; Herb v. Pitcairn, 324 U.S. 117, 125-26 (1945), overruled on other grounds by Michigan v. Long, 463 U.S. 1032 (1983).

51. 463 U.S. at 1041. 
sions rest on state grounds if state courts want to insulate their decisions from Supreme Court review.

Some New Federalism proponents have condemned Long because they view it as resting on a presumption that state courts will decide cases on federal grounds, a presumption that they consider disrespectful to state sovereignty and contrary to established principles of federalism.52 This criticism is greatly overblown. Not only can the Long requirement of clarity be satisfied simply by adding a caption or explanatory sentence to a court's opinion, ${ }^{53}$ but it requires state courts to do exactly what New Federalism proponents have been urging them to do: think explicitly about the grounds of their decisions, and make those grounds clear in their opinions. ${ }^{54}$

All in all, New Federalism advocates seem unremittingly optimistic about the prospects for achieving the movement's goals. They point with pride to the fact that state courts have decided over four hundred cases construing state constitutions to provide greater protections for individual rights than the federal Constitution. ${ }^{55}$ They write articles about state constitutional law with titles that include words such as "revival," "reincarnation," "renaissance," "revolution," and "reemergence." T6 They devote close scholarly attention to independent state constitutional decisions, ${ }^{57}$ and they have held numerous sym-

52. See, e.g., William W. Greenhalgh, Independent and Adequate State Grounds: The Long and the Short of $I t$, in Developments IN STATE CONSTitutional LaW, supra note 7, at 211, 214-21.

53. The New Hampshire Supreme Court routinely does this. See infra notes $172-74$ and accompanying text.

54. Joseph R. Grodin, Some Reflections on State Constitutions, 15 Hastings Const. L.Q. 391, 399 (1988). See also PruneYard Shopping Ctr. v. Robins, 447 U.S. 74 (1980). There the Supreme Court refused to disturb on federal constitutional grounds a California ruling that the state constitution provided greater protections to freedom of speech than did the federal Constitution. 447 U.S. at 88. In reaching this decision the Court relied on the California Supreme Court's clearly stated reasons for concluding that broader state-protected rights of expression did not impermissibly infringe on appellants' federal property or First Amendment rights. 447 U.S. at 78, 83-84.

55. David Schuman, The Right to "Equal Privileges and Immunities": A State's Version of "Equal Protection," 13 VT. L. Rev. 221, 221 (1988); see also Sol Wachtler, Our Constitutions Alive and Well, 61 ST. JoHN's L. REv. 381, 397 (1987) (stating that state courts issued 350 such opinions between 1970 and 1984).

56. Abrahamson, supra note 29, at 951; Brennan, Bill of Rights, supra note 1, at 535; James C. Harrington, Reemergence of Texas Constitutional Protection, 2 EMERgING Issues IN ST. CoNST. L. 101, 101 (1989); Howard, supra note 33, at 1; Symposium on the Revolution in State Constitutional Law, 13 VT. L. REv. 11, 11 (1988).

57. See, e.g., John H. Buttler, Oregon's Constitutional Renaissance: Federalism Revisited, 13 VT. L. REv. 107 (1988); Galie, supra note 33; Howard, supra note 33; Howard, supra note 25; Levinson, supra note 25, at 51; Simon, supra note 31; Wilkes, supra note 6; Donald E. Wilkes, Jr., The New Federalism in Criminal Procedure in 1984: Death of the Phoenix?, in Developments IN STATE CONSTITUTIONAL LAW, supra note 7, at 166; Williams, supra note 6. 
posia on state constitutional law. ${ }^{58}$ A new journal called Emerging Issues in State Constitutional Law has even been established to provide a forum for such commentary. 59

Is this optimism well founded? Have state courts responded to Justice Brennan's call and begun to develop, in the past fifteen years, an independent jurisprudence of state constitutional law? The answer will be found by examining current state constitutional discourse. If a robust, independent state constitutional law exists, it must be manifested by an equally robust and independent state constitutional discourse that allows participants in state legal systems to raise, debate, and adjudicate claims about the meaning of state constitutions. ${ }^{60}$

New Federalism predicts that such a discourse could take two possible forms. If a state adopted the primacy approach to constitutional adjudication, it would develop a state constitutional discourse in which intelligible claims about the meaning of the state constitution could be based on the text, history, structure, and underlying values of the state constitution. Such a discourse would in all likelihood closely resemble federal constitutional discourse in tone and style, although its participants would be free to accept or reject the legitimacy of any or all of the language or conventions of the cognate federal discourse. Moreover, any similarities in case outcomes or doctrine would be purely fortuitous, since the state discourse would stand on its own. Thus, if a state court happened to reach the same result under the state constitution as the federal courts have reached under the U.S. Constitution, that congruity might only reflect the fact that both constitutions are rooted in similar historical or political circumstances.

If a state adopted an interstitial approach to constitutional adjudication, its state constitutional discourse would take a slightly different form. Instead of being independent and internally complete, such a discourse would focus on the ways in which the state and federal con-

58. E.g., Developments in State Constrtutional LaW, supra note 7 (Williamsburg Conference); State Constitutions in a Federal System, 496 ANNAIS AM. ACAD. PoL. \& Soc. SCI. 1 (1988); Symposium on State Constitutional Jurisprudence, 15 HASTINGS CoNST. L.Q. 391 (1988); Symposium on State Constitutional Law, 64 WASH. L. REV. 1 (1989); Symposium on the Revolution in State Constitutional Law, supra note 56; Symposium, The Emergence of State Constitutional Law, 63 TeXas L. Rev. 959 (1985); Symposium, Special Section: The Connecticut Constitution, 15 CONN. L. REV. 7 (1982).

59. The journal is published by the National Association of Attorneys General. The inaugural issue appeared in 1988.

60. See supra section I.B. This is a very different method of evaluating the condition of state constitutional law than that employed by many New Federalists, who seem to view the number of state decisions deviating from federal law as an important indicator of the health of state constitutional law. However, deviations from federal law alone do not necessarily indicate the presence of a robust and independent state constitutional discourse. See infra notes 143-50 and accompanying text. 
stitutions differ from each other. Thus, state constitutional discourse would be a "discourse of distinctness" - it would comprise a language and set of conventions enabling participants in the legal system to argue that provisions of the state constitution mean something different from their federal counterparts. Because this discourse would use federal constitutional discourse as a starting point, it would probably have to incorporate the various elements of federal constitutional discourse such as text, framers' intent, constitutional theory, judicial precedent, and societal values. However, state constitutional discourse would contain additional features that would allow participants to apply these elements of federal constitutional discourse to the state constitution and to construct intelligible arguments that the state and federal constitutions differ in dispositive ways. ${ }^{61}$

It is possible, and perhaps likely, that these two different types of state constitutional discourse would end up looking very much the same. If there were an irreducible difference between them, it would be this: while both types of discourse would yield meanings for the state constitution, participants in a discourse accompanying the interstitial approach would care fundamentally about the meaning of the federal Constitution, whereas participants in a discourse accompanying the primacy approach would not.

With this discussion in mind, we now have the tools to assess the optimistic claims of New Federalism. In the next Part, I review state constitutional discourse as it was practiced in 1990, and conclude that it not only falls immensely short of New Federalism ideals, but often seems barely to exist at all. ${ }^{62}$

\section{The Poverty of State Constitutional Discourse}

The editors of the Draft Model State Constitution have accurately observed that there can really be no such thing as a model state constitution because there is no such thing as a model state. ${ }^{63}$ It unfortunately follows that the only completely accurate way to examine the status of state constitutional law would be to look at every relevant

61. The interstitial approach is generally less applicable to state constitutional provisions without federal analogue, of which there are many. See infra notes 243-55 and accompanying text. Proponents of the interstitial approach have not outlined how they would interpret such provisions, but it seems that they would be driven by necessity to use something like the primacy approach.

62. I should note here that the reader who is willing to accept my conclusions about the poverty of state constitutional discourse, whether from personal experience or on faith, can skip the following Part and turn directly to my analysis of the problem in Parts IV and V without loss of continuity.

63. National Municipal League, Model State Constitution vii (rev. 6th ed. 1968). 
decision of every state court. That would have made my project unmanageable, so I have narrowed the field of inquiry in four ways. First, I have confined myself to a sampling of seven states: New York, Massachusetts, Virginia, Louisiana, California, Kansas, and New Hampshire. ${ }^{64}$ Second, I have examined only decisions of the highest court of each state. 65 Third, I have excluded decisions in which the state high court did not write a full opinion, or at least perform some kind of legal analysis. Thus, I have not considered summary or memorandum decisions, or any other type of decision that does not reveal in the decision itself the nature of the case and the court's reasoning. Finally, I have confined my analysis to cases decided during a single year, 1990, the most recent for which published state high court deci-

64. I selected this sample in the following way. Going into the research, I hypothesized that five factors might be relevant to the condition of constitutional law and discourse in any given state: (1) the size of the state; (2) its age; (3) the presence of an unusual founding history; (4) the continuity of its constitutional traditions; and (5) the nature of the constitutional text. The size of the state would be relevant because of the sheer number of cases litigated: the more constitutional cases litigated, the more constitutional rulings made, and the more developed the state's body of constitutional law. The age of the state would be relevant for the same reason; older states would have had a longer period in which to develop a substantial body of constitutional rulings. An unusual founding history would be relevant in that it might be reflected in the state constitution, thereby providing an occasion for developing constitutional doctrines different from federal constitutional law. The presence of such differences might then serve as a focal point for the development of a strong, independent body of state constitutional law. The continuity of a state's constitutional traditions would be relevant in two ways. First, a constitution in long continuous use is more likely to be extensively construed than a relatively new document. Second, a history of frequent constitutional revisions might be indicative of an approach by the people of the state toward constitutional law that differs from the approach taken by the nation toward the national Constitution. Finally, peculiarities of the constitutional text might be the occasion for developing independent bodies of state constitutional law; they might also indicate underlying state attitudes concerning the functions that constitutions ought to serve. In looking at state constitutions in this last category, however, it became clear that the search for "peculiarities" would be too subjective, so I decided eventually to look only at the length of the constitutional text.

According to these criteria, a representative sample of states would include states of varying sizes, ages, and histories, with constitutional traditions of varying continuity and constitutions of varying lengths. To keep the sample size manageable, $I$ tried to choose states that were interesting for more than one quality. The states selected fit the criteria as follows. New York and California are very large, and New Hampshire is very small. New York, Massachusetts, Virginia, and New Hampshire are very old states; Louisiana, Kansas, and California are intermediate to young. I avoided extremely young states such as Alaska and Hawaii because it seemed unlikely that they have had the time necessary to develop a substantial body of constitutional law. Louisiana has an unusual history of French and Spanish influence, and is the only state in the union to retain a civil law system. New York, with its background of early Dutch settlement, also has a somewhat atypical history. With respect to continuity, Massachusetts and New Hampshire have had only one constitution each since they became states; Lovisiana has had eleven constitutions, the most of any state. Finally, the New Hampshire and Massachusetts constitutions are among the shortest of state constitutions, the New York constitution among the longest. Kansas fell into the middle of the pack in virtually every category, and was selected for that reason.

65. This is probably just as well, since it seems that state supreme courts are far more likely to devote sustained attention to state constitutional issues than are lower state courts. Also, it is often difficult to obtain good data on state trial court decisions. In contrast, state supreme court opinions are all published and readily available. 
sions were available. ${ }^{66}$ These reductions yielded an overall sample size of 1208 cases.

In addition to systematically examining the cases included in the sample, I have also delved more anecdotally into decisions rendered in other states and in different years. This spot-checking supports the conclusions derived from studying the primary sample.

\section{A. General Trends}

\section{The Infrequency of State Constitutional Decisions}

One of the most striking aspects of state constitutional decisions is their relative infrequency. In calendar year 1990, the U.S. Supreme Court issued 137 full opinions, of which 73, or 53\%, involved resolution of at least one federal constitutional issue. None of the state courts surveyed here construed its own state constitution with anything remotely approaching that frequency. Even using the most generous method of counting state constitutional decisions, ${ }^{67}$ the courts of the sample states decided state constitutional issues in only about $21 \%$ of their cases, or about $40 \%$ as often as the U.S. Supreme Court construed the federal Constitution. Broken down by state, the rates were California, 31\%; Massachusetts, 24\%; New Hampshire, 26\%; New York, 20\%; Kansas, $18 \%$; Louisiana, $15 \%$; and Virginia, $7 \% .{ }^{68}$

66. While focusing on a single year may result in some distortion due to annual variations in caseload and the like, I suspect that the more recent the focus, the more any distortion would tend to favor the predictions of New Federalism. This is because independent state constitutional decisions are more likely with the passage of time, for two reasons. First, the more recent the year, the more time the message of the New Federalism has had to penetrate the state judiciaries. Second, the U.S. Supreme Court continues each year to slow or reverse the expansion of federally protected rights, thus providing state courts with more to react against, to the extent that their constitutional jurisprudence is at heart a reactive one.

67. A small percentage of the opinions surveyed were unclear as to whether the courts' holdings rose to constitutional dimensions; a much larger percentage were unclear as to whether the courts' rulings were based on the state or federal constitution. For the purpose of comparing constitutional decision rates, I have counted all these ambiguous decisions among the state constitutional rulings. However, I have excluded rulings that unambiguously relied only on the U.S. Constitution. For a more complete breakdown of state decisions, see infra note 68 . For a discussion of cases that do not clearly identify the constitution upon which the court relies, see infra notes $85-98$ and accompanying text.

68. The actual numbers are as follows (all figures refer to cases decided in 1990). In 1990, the New York Court of Appeals issued 240 opinions containing some kind of legal analysis. Of these, 184 involved no constitutional issue of any kind, 7 involved only a federal constitutional claim, and 37 dealt with state constitutional claims. An additional 12 opinions left unclear whether the holding of the case rose to constitutional dimensions. During the same period, the Massachusetts Supreme Judicial Court issued 273 full opinions. Of these, 186 involved no constitutional issues, 12 raised only a federal constitutional issue, 62 arguably dealt with at least one state constitutional question, and in 13 cases it was unclear whether the ruling had constitutional dimensions.

The Virginia Supreme Court over the same period issued 147 full opinions. Of these, 130 involved no constitutional issue, 7 raised only a federal constitutional claim, and 8 arguably involved state constitutional claims. In another 2 cases, it was unclear whether the ruling had 
State constitutional law thus comprises a significantly smaller proportion of the state high court docket than federal constitutional law does for the Supreme Court. Although it is not clear from this data alone whether the dearth of state constitutional cases is due to the failure of litigants to raise such claims or to a weeding out of constitutional cases due to jurisdictional or procedural considerations, I suggest reasons below to suspect the former. Either way, the lack of decisions alone retards the development of state constitutional law and discourse - the development of a language, after all, requires the opportunity to speak. ${ }^{69}$

\section{Grudging Resort to the State Constitution}

Just as striking as the infrequency of state constitutional decisions, and undoubtedly one of its causes, is what can only be characterized as a general unwillingness among state supreme courts to engage in any kind of analysis of the state constitution at all. I will use New York as an example, although this unwillingness exists to an equal or greater extent in Massachusetts, Virginia, and Kansas, and to a somewhat lesser extent in California and Louisiana.

The grudging character of the New York Court of Appeals' state constitutional analyses permeates the great majority of its decisions in the sample. In 1990, the court decided 37 cases that can arguably be viewed as resting in whole or in part on the state constitution. In 12 of them, the only mention of the state constitution consists of either a passing acknowledgement that a party is raising a state constitutional claim; a citation, without further comment, to the state constitution; or the bare assertion that the case comes out the same way under both the state and federal constitutions. ${ }^{70}$ In other words, the opinions con-

constitutional dimensions. The Louisiana Supreme Court issued 149 full opinions, of which 119 involved no constitutional issue, 8 raised only federal constitutional issues, 21 dealt with at least one state constitutional issue, and one was unclear as to its constitutional roots.

The California Supreme Court issued 118 full opinions in 1990, of which 36 contained at least one issue of state constitutional law. An additional 76 involved no constitutional issue, and 6 cases dealt only with federal constitutional issues. The Kansas Supreme Court issued 142 opinions; 100 of these raised no constitutional issue, 16 dealt only with federal constitutional issues, 21 involved or arguably involved state constitutional issues, and in 5 cases it was unclear whether the case had constitutional dimensions.

In 1990, the New Hampshire Supreme Court issued 139 full opinions. Of these, 98 did not address any constitutional question, 34 dealt with state constitutional claims, 5 involved only federal claims, and in 2 cases it was unclear whether the case had constitutional dimensions.

69. This may be especially true given that state constitutions are on average almost four times as long as the U.S Constitution. Albert L. Sturm, The Development of American State Constitutions, 12 PUbLIUS 57, 74-76 (1982). It seems logical that state constitutions would thus require considerably more exegesis than the federal Constitution in order to play a comparable role in state law.

70. People v. Carter, 566 N.E.2d 119, 120, 123 (N.Y. 1990), cert. denied, 111 S. Ct. 1599 (1991); Johnson Newspaper Corp. v. Melino, 564 N.E.2d 1046, 1047, 1049 (N.Y. 1990); People 
tain nothing that could be regarded as analysis of the state constitution. In 12 more opinions, there is no mention of or citation to any constitution; the court merely holds that some "right" or "constitutional right" is at issue. ${ }^{71}$

Consider some examples. In People v. Sides, ${ }^{72}$ a criminal defendant claimed inadequate assistance of counsel under both the state and federal constitutions. The court held that the defendant's "right to counsel" had been violated, but gave no indication of whether the relevant right was a state or federal one. ${ }^{73}$ In People v. Cain, ${ }^{74}$ the court reversed a conviction on the ground that the defendant had been denied his "right to be present, with counsel, at all material stages of a trial."75 The court then cited both the U.S. and New York constitutions, but did not say whether its ruling rested on one or both. ${ }^{76}$ In In re Jamal C., 77 the court ruled that the respondent had "no constitutional right to the presence of counsel."78 The court did not cite any constitution at all. In none of these cases did the court make any statement of the kind required by Michigan $v$. Long to the effect that its decision rested on adequate and independent state grounds.

In each of these cases it is essentially impossible to determine by reading the case whether it is a state constitutional ruling at all. Such cases squelch the development of state constitutional discourse in at least two ways. First, ambiguity about the basis of the court's ruling

v. Ortiz, 564 N.E.2d 630, 632 (N.Y. 1990); Schneider v. Sobol, 558 N.E.2d 23, 24 (N.Y. 1990); McKenzie v. Jackson, 556 N.E.2d 1072 (N.Y. 1990); People v. Basora, 556 N.E.2d 1070, 1071 (N.Y. 1990); People v. Cain, 556 N.E.2d 141, 143 (N.Y. 1990); Seelig v. Koehler, 556 N.E.2d 125, 126 (N.Y. 1990), cert. denied, 111 S. Ct. 134 (1990); Forti v. New York State Ethics Commn., 554 N.E.2d 876, 882-86 (N.Y. 1990); People v. Hernandez, 552 N.E.2d 621, 624 (N.Y. 1990), affd. sub nom. Hernandez v. New York, 111 S. Ct. 1859 (1991); People v. Sides, 551 N.E.2d 1233, 1234 (N.Y. 1990); People v. Cintron, 551 N.E.2d 561, 566, 567 (N.Y. 1990).

71. People v. Rodriguez, 564 N.E.2d 658, 659 (N.Y. 1990) ("due process right to be present at trial"); People v. LaClere, 564 N.E.2d 640, 641 (N.Y. 1990) ("right to counsel"); People v. Thomas, 563 N.E.2d 280, 281 (N.Y. 1990) ("right to have counsel at the lineup"); People v. Gordon, 563 N.E.2d 274, 275 (N.Y. 1990) ("showup identification"); City of New York v. State, 562 N.E.2d 118, 121 (N.Y. 1990) ("equal protection argument"); People v. Harris, 559 N.E.2d 660, 661 (N.Y. 1990) ("due process" right); In re Lionel F., 558 N.E.2d 30, 31 (N.Y. 1990) ("double jeopardy"), cert. denied, 111 S. Ct. 304 (1990); People v. Garcia, 555 N.E.2d 902, 902 (N.Y. 1990) ("ineffective assistance of counsel"); People v. Wandell, 554 N.E.2d 1274, 1274 (N.Y. 1990) ("effective assistance of counsel"); People v. Gonzales, 554 N.E.2d 1269, 1270 (N.Y. 1990) ("right to counsel"), cert. denied, 111 S. Ct. 99 (1990); In re Jamal C., 553 N.E.2d 1018, 1019 (N.Y. 1990) ("constitutional right to the presence of counsel"); People v. Tuck, 551 N.E.2d 578,578 (N.Y. 1990) ("right to confrontation").

72. 551 N.E.2d 1233, 1234 (N.Y. 1990).

73. 551 N.E. $2 d$ at 1235.

74. 556 N.E.2d 141 (N.Y. 1990).

75. 556 N.E.2d at 143.

76. 556 N.E.2d at 143.

77. 553 N.E.2d 1018 (N.Y. 1990).

78. 553 N.E.2d at 1019. 
impairs the usefulness of a case for the purpose of debating the meaning of the state constitution. This is because it is highly awkward, if not impossible, to use a case as the basis for an argument about the meaning of the state constitution if it is unclear from the case itself whether the case is even about the state constitution.

Second, such ambiguity is self-perpetuating. Suppose one party claims that a case construes the state constitution and the other party contends that it deals with the federal Constitution. It is very unlikely that a state court, particularly a lower court, will attempt to resolve such a dispute. In all likelihood, the court will hold that it need not resolve the ambiguity; all we need to know, the court will say, is that controlling state precedent recognizes the existence of a constitutional right in the circumstances at hand. Consequently, the court need only apply the ambiguous case, resulting in a ruling of equal ambiguity. Eventually, a small body of law may evolve that cannot be traced with any confidence to either the state or federal constitutions. ${ }^{79}$ Such a development can only inhibit the creation of a robust state constitutional discourse. The most fundamental requirement for the creation of a discourse is agreement concerning when participants should be understood to be engaging in the discourse. Decisions such as these virtually preclude any such understanding.

Just as important, however, is the message that the court sends when, like the New York Court of Appeals, 65\% of its decisions explicitly or arguably involving the state constitution share these flaws. The message is: "This activity is not important to us. We will not treat such claims with much attention or care, so you are probably wasting your time raising them." It is hard to conceive of a lawyer who would spend much time developing a thorough or novel state constitutional claim after receiving such a message from the state's highest court.

The result of the Court of Appeals' approach to state constitutional claims has been to discourage litigants from making such claims at all. This discouragement appears between the lines of New York decisions, which show their disdain for the state constitution by giving short shrift to the great majority of state constitutional claims. But another important sign of this discouragement is the comparatively low proportion of cases - probably no more than $15 \%^{80}$ - on the

79. For an example of this, see the discussion of State v. Prewett, infra notes $96-98$ and accompanying text.

80. See supra note 68 for a numerical breakdown of decisions. The $15 \%$ figure is derived by counting state constitutional decisions in a more realistic way than they were counted in note 67 , supra, that is, by excluding from the total those decisions that were unclear as to whether they 
Court of Appeals docket that even request a state constitutional ruling of any kind.

This last conclusion is borne out by other data. For example, both the New York and U.S. constitutions protect the freedom of speech. ${ }^{81}$ In 1990, New York trial courts issued a total of 3 published opinions dealing with free speech claims under the state constitution. ${ }^{82}$ During the same period, U.S. district courts sitting in New York issued 15 published opinions adjudicating free speech claims under the First Amendment. ${ }^{83}$ This suggests that when litigants in New York had a choice of going to federal or state court on constitutional issues dealing with free speech, they overwhelmingly chose to go to federal court, even though they may thereby have lost the chance to raise a claim under the state constitution. Obviously, these litigants placed a very low value on the opportunity to raise a state constitutional claim. ${ }^{84}$

had any sort of constitutional dimension. That leaves 37 out of 240 cases, or approximately $15 \%$.

81. U.S. CONST. amend. I; N.Y. CoNST. art. I, § 8.

82. People v. Perkins, 558 N.Y.S.2d 459 (Dist. Ct. 1990); People v. Reynolds, 554 N.Y.S.2d 391 (City Ct. 1990); People v. Blanchette, 554 N.Y.S.2d 388 (City Ct. 1990). A fourth case, People v. Pennisi, 563 N.Y.S.2d 612 (Sup. Ct. 1990), is unclear as to whether the constitutional claim adjudicated is a federal or state claim. A fifth case, Delano Village Cos. v. Orridge, $\mathbf{5 5 3}$ N.Y.S.2d 938 (Sup. Ct. 1990), seems clearly to decide a free speech claim under the federal Constitution but is unclear about whether the ruling should also be understood as one under the state constitution. Also during 1990, the Court of Appeals decided 2 free speech claims under the state constitution. Johnson Newspaper Corp. v. Melino, 564 N.E.2d 1046 (N.Y. 1990); Golden v. Clark, 564 N.E.2d 611 (N.Y. 1990). Research for this footnote was confined to published decisions.

83. Piesco v. City of New York, 753 F. Supp. 468 (S.D.N.Y. 1990) (retaliatory discharge); New York News, Inc. v. Metropolitan Transp. Auth., 753 F. Supp. 133 (S.D.N.Y. 1990) (restricting sale of newspapers); Levin v. Harleston, 752 F. Supp. 620 (S.D.N.Y. 1990) (academic freedom); Central Am. Refugee Ctr. v. City of Glen Cove, 753 F. Supp. 437 (E.D.N.Y. 1990) (seeking employment); New York State Assn. of Career Schools v. State Educ. Dept., 749 F. Supp. 1264 (W.D.N.Y. 1990) (regulation of schools); Uryevick v. Rozzi, 751 F. Supp. 1064 (E.D.N.Y. 1990) (employment rules); New Alliance Party v. Dinkins, 743 F. Supp. 1055 (S.D.N.Y. 1990) (regulation of political party rally); Wojnarowicz v. American Family Assn., 745 F. Supp. 130 (S.D.N.Y. 1990) (state copyright law); Don King Prods., Inc. v. Douglas, 742 F. Supp. 778 (S.D.N.Y. 1990) (libel); New York State Natl. Org. for Women v. Terry, 737 F. Supp. 1350 (S.D.N.Y. 1990) (civil rights); Starace v. Chicago Tribune Co., 17 Media L. Rep. (BNA) 2330 (S.D.N.Y. 1990) (libel); Selkirk v. Boyle, 738 F. Supp. 70 (E.D.N.Y. 1990) (public employment); Bordell v. General Elec. Co., 732 F. Supp. 327 (N.D.N.Y. 1990) (workplace confidentiality); Saraceno v. City of Utica, 733 F. Supp. 538 (N.D.N.Y. 1990) (retaliatory discharge); Young v. New York City Transit Auth., 729 F. Supp. 341 (S.D.N.Y. 1990) (regulation of begging).

Again, research did not extend to unpublished district court opinions. Also excluded from this group are any cases that could not reasonably have been adjudicated in state court. For example, 14 cases in which the United States was a plaintiff or defendant have been excluded.

84. This result is even more surprising given the New York Court of Appeals' explicit assertion that the state constitution provides greater protection for free speech than the federal Constitution. Immuno AG. v. Moor-Jankowski, 567 N.E.2d 1270, 1277-78 (N.Y. 1991); O'Neill v. Oakgrove Constr., 523 N.E.2d 277, 280 n.3 (N.Y. 1988). On the other hand, even when the court claims to expand constitutional protection, it seems to do so in a way that does not greatly assist the development of a state constitutional discourse. For example, the court has said that New York "has its own exceptional history and rich tradition" of freedom of the press, Immuno 


\section{Obscurity Concerning the Basis of Rulings}

One aspect of the grudging character of state constitutional decisions discussed above is the failure of the court to specify whether its analyses and rulings relied on the state or federal constitutions. This obscurity is so prevalent, however, that it requires separate discussion. It has already been noted that a substantial proportion of the New York decisions share this flaw. The situation in other states is similar.

In 29 cases decided by the Massachusetts Supreme Judicial Court the court failed entirely to specify whether certain of the parties' claims, much less its own analysis and ruling, rested on state or federal constitutional grounds, or both. ${ }^{85}$ For example, in Commonwealth v. Matthews, ${ }^{86}$ the defendant claimed, according to the court, that the exclusion of certain jurors violated his "constitutional right to a random selection of jurors from a fair cross-section of the community." 87 The court did not say whether the defendant's "constitutional right" was a state or federal one and, although it cited only Massachusetts

$A G ., 567$ N.E.2d at 1278 , but it fails to define that history and tradition and to explain why they require results that differ from federal law. For a discussion of this assertion/counterassertion problem, see infra notes $141-50$ and accompanying text.

85. Commonwealth v. Lanoue, 563 N.E.2d 1367, 1369 (Mass. 1990) (inadequate assistance of counsel); Commonwealth v. Todd, 563 N.E.2d 211, 213 (Mass. 1990) (suppression of statement); Strasnick v. Board of Registration in Pharmacy, 562 N.E.2d 1333, 1337-38 (Mass. 1990) (due process); Commonwealth v. Colon-Cruz, 562 N.E.2d 797, 802-05 (Mass. 1990) (suppression of confession, suggestive identification); Commonwealth v. Rosado, 562 N.E.2d 790, 795-96 (Mass. 1990) (inadequate assistance of counsel); Commonwealth v. Colon, 558 N.E.2d 974, 97982 (Mass. 1990) (suppression of confession); Commonwealth v. Zagranski, 558 N.E.2d 933, 935 (Mass. 1990) (probable cause); Commonwealth v. Tart, 557 N.E.2d 1123, 1130-31 (Mass. 1990) (self-incrimination); Commonwealth v. Moses, 557 N.E.2d 14, 16-18 (Mass. 1990) (stop and frisk); Commonwealth v. Bousquet, 556 N.E.2d 37, 41-43 (Mass. 1990) (suppression, inadequate assistance of counsel); Commonwealth v. Dunn, 556 N.E.2d 30, 32-35 (Mass. 1990) (suppression issues); Luna v. Superior Court, 555 N.E.2d 881, 883 (Mass. 1990) (waiver of privilege against self-incrimination); Commonwealth v. Roberts, 555 N.E.2d 588, 589-90 (Mass. 1990) (suppression of defendant's statement); Commonwealth v. Pratt, 555 N.E.2d 559, 566-67 (Mass. 1990) (search warrant sufficiency); Commonwealth v. Perrot, 554 N.E.2d 1205 (Mass. 1990) (suppression issue); Commonwealth v. Downey, 553 N.E.2d 1303, 1307 (Mass. 1990) (suppression of pretrial identification); Richardson v. Sheriff of Middlesex County, 553 N.E.2d 1286, 1290-93 (Mass. 1990) (prison conditions); Commonwealth v. Mamay, 553 N.E.2d 945, 952-53 (Mass. 1990) (inadequate assistance of counsel); Care \& Protection of Martha, 553 N.E.2d 902, 908 (Mass. 1990) (due process); Commonwealth v. Couture, 552 N.E.2d 538, 539-40 (Mass. 1990) (probable cause); Commonwealth v. Gomes, 552 N.E.2d 101, 104-05 (Mass. 1990) (right to counsel); Commonwealth v. Robbins, 552 N.E.2d 77, 79-80 (Mass. 1990) (suppression in connection with search of auto; requires application of "constitutional principles"); Commonwealth v. Berrio, 551 N.E.2d 496, 499 (Mass. 1990) (due process); Commonwealth v. Davis, 551 N.E.2d 39, 41-42 (Mass. 1990) (due process, equal protection); Commonwealth v. Yesilciman, 550 N.E.2d 378, 382-83 (Mass. 1990) (adequacy of search warrant); Commonwealth v. Pope, 549 N.E.2d 1120, 1126 n.8 (Mass. 1990) (ineffective assistance of counsel); Commonwealth v. Bembury, 548 N.E.2d 1255, 1261-62 (Mass. 1990) (due process); Commonwealth v. Durning, 548 N.E.2d 1242, 1247-48 (Mass. 1990) (due process); Commonwealth v. Matthews, 548 N.E.2d 843, 848 (Mass. 1990) (right to jury representing fair cross-section of community).

86. 548 N.E.2d 843 (Mass. 1990).

87. 548 N.E.2d at 848. 
cases in its analysis, gave no indication, such as a Long statement, that its analysis rested on state constitutional grounds.

In 9 cases, the court went so far as to state explicitly that the litigants were raising a claim under both the state and federal constitutions, but then failed to specify the basis of its own analysis. ${ }^{88}$ For example, Commonwealth v. Purdy ${ }^{89}$ involved a cruel and unusual punishment claim under both the federal and state constitutions. In ruling on the claim, the court relied on one Massachusetts and one federal case, cited to neither the state nor federal constitution, and made no Long statement. It is thus impossible to tell whether this case should be considered part of state or federal constitutional discourse.

The Virginia Supreme Court decided only 8 cases that can plausibly be viewed as involving state constitutional issues..$^{90}$ In 6 of these cases the court failed to specify whether its analysis dealt with the federal or state constitution. Typical is Brown v. Brown, ${ }^{91}$ which dealt with an unidentified procedural due process issue. The courts of Louisiana $^{92}$ and California ${ }^{93}$ also regularly failed to specify the basis of

88. Commonwealth v. Scott, 564 N.E.2d 370, 374-75 (Mass. 1990) (right to exculpatory evidence); Commonwealth v. Purdy, 562 N.E.2d 1347, 1351-52 (Mass. 1990) (cruel and unusual punishment); Commonwealth v. Rosado, 562 N.E.2d 790, 794 (Mass. 1990) (right to speedy trial); Commonwealth v. Cameron, 553 N.E.2d 898 (Mass. 1990) (roadblock); Commonwealth v. Freeman, 552 N.E.2d 553, 555-57 (Mass. 1990) (due process/tainted grand jury); Commonwealth v. Rutkowski, 550 N.E.2d 362, 363-64 (Mass. 1990) (warrant description); Commonwealth v. Pope, 549 N.E.2d 1120, 1125-26 (Mass. 1990) (right to remain silent); Commonwealth v. Durning, 548 N.E.2d 1242, 1248-50 (Mass. 1990) (due process right to present a defense); Commonwealth v. Santoro, 548 N.E.2d 862, 863-64 (Mass. 1990) (standing to challenge search).

89. 562 N.E.2d 1347 (Mass. 1990).

90. Brown v. Brown, 397 S.E.2d 837, 839 (Va. 1990); Commonwealth v. Burns, 395 S.E.2d 456, 458-460 (Va. 1990); Hamer v. School Board, 393 S.E.2d 623, 625-626 (Va. 1990); Hess v. Snyder Hunt Corp., 392 S.E.2d 817, 820-821 (Va. 1990); R.G. Moore Bldg. Corp. v. Committee for the Repeal of Ordinance R(C)-88-13, 391 S.E.2d 587, 591 (Va. 1990); Mu'min v. Commonwealth, 389 S.E.2d 886, 890-891, 892-893 (Va. 1990); Smith v. Commonwealth, 389 S.E.2d 871, 876 (Va. 1990); Occoquan Land Development Corp. v. Cooper, 389 S.E.2d 464, 467 (Va. 1990). Only in R.G. Moore and Hess did the court clearly state whether its analysis was based on the federal or state constitutions.

91. 397 S.E.2d 837 (Va. 1990).

92. Of 21 arguably relevant constitutional decisions, $9(43 \%)$ failed to specify whether the constitution under discussion was the state or federal one. State v. Byrd, 568 So. 2d 554, 560-61 (La. 1990) (scope of search warrant); State v. Roberts, 568 So. 2d 1017, 1019 (La. 1990) (due process/"fundamental fairness"); Louisiana State Bar Assn. v. Keys, 567 So. 2d 588, 591 (La. 1990) (due process); Palermo Land Co. v. Planning Commn., 561 So. 2d 482, 491-96 (La. 1990) (due process); State v. Burrell, 561 So. 2d 692, 698-99 (La. 1990) (fair trial/change of venue), cert. denied, 111 S. Ct. 799 (1991); State v. Wille, 559 So. 2d 1321, 1335-36, 1338-39 (La. 1990) (vagueness, ineffective assistance of counsel); State v. Lee, 559 So. 2d 1310, 1313-15 (La. 1990) (exclusion of blacks from venire); State v. Jones, 558 So. 2d 546, $551-52$ (La. 1990) (vagueness); Caracci v. Louisiana State Racing Commn., 556 So. 2d 1249 (La. 1990) (due process).

93. Almost all of the 36 decisions rendered by the California Supreme Court in 1990 that handled state constitutional issues were death penalty appeals. While the death penalty review cases of the California Supreme Court are noteworthy for their clarity and thoroughness, the court still issued 23 opinions in which at least one constitutional issue was analyzed without any indication of whether the constitutional analysis was based on the federal or state constitution. 
their constitutional rulings, although to a somewhat lesser extent.

The Kansas Supreme Court has raised ambiguity about the constitutional basis of judicial rulings to something of an art form. In 13 out of 21 relevant cases, the court referred to some sort of constitutional right without specifying its source. ${ }^{94}$ To further confuse things, in 6 cases the court held opaquely that it "adopted" the relevant federal standard. ${ }^{95}$ For example, in State $v$. Prewett ${ }^{96}$ the court discussed a

People v. Hayes, 802 P.2d 376, 393, 397, 398, 401, 402, 413-15 (Cal. 1990) (ineffective assistance of counsel), cert. denied, 60 U.S.L.W. 3359 (1991); People v. Benson, 802 P.2d 330, 353-57 (Cal. 1990) (prosecutorial misconduct), cert. denied, 116 L. Ed. 2d 277 (1991); People v. Kaurish, 802 P.2d 278, 289-90, 305-06 (Cal. 1990) (prosecutorial misconduct, inadequate assistance of counsel, equal protection), cert. denied, 112 S. Ct. 121 (1991); People v. Gallego, 802 P.2d 169, 188-89, 192-93, 204-06 (Cal. 1990) (waiver of counsel, venue/fair trial, prosecutorial misconduct), cert. denied, 116 L. Ed. 2d 277 (1991); People v. Anderson, 801 P.2d 1107, 1112-14, 1116-18 (Cal. 1990) (dilution of juror sense of responsibility, prosecutorial misconduct), cert. denied, $112 \mathrm{~S}$. Ct. 148 (1991); People v. Gonzalez, 800 P.2d 1159, 1202-03 (Cal. 1990) (ineffective assistance of counsel), cert denied, 112 S. Ct. 117 (1991); In re Crooks, 800 P.2d 898 (Cal. 1990) (due process, double jeopardy); People v. Ortiz, 800 P.2d 547, 552, 555-56 (Cal. 1990) (right to counsel, due process); People v. Kelly, 800 P.2d 516, 530-31, 533-34, 537-39 (Cal. 1990) (venue/fair trial, juror bias, prosecutorial misconduct), cert. denied, 112 S. Ct. 117 (1991); People v. Medina, 799 P.2d 1282, 1297-99, 1303 (Cal. 1990) (prosecutorial misconduct, "right to be personally present"), cert. granted in part and motion granted, 116 L. Ed. 2d 276 (1991); People v, Frank, 798 P.2d 1215, 1221, 1223, 1225-26 (Cal. 1990) (double jeopardy, ineffective assistance of counsel, prosecutorial misconduct), cert. denied, 111 S. Ct. 2816 (1991); People v. Sanders, 797 P.2d 561, 580-81 (Cal. 1990) (due process), cert. denied, 111 S. Ct. 2249 (1991); People v. Rodriguez, 795 P.2d 783 (Cal. 1990) (due process); People v. Stankewitz, 793 P.2d 23, 43-44, 45, 50-53 (Cal. 1990) (juror bias, discriminatory peremptory challenges, ineffective assistance of counsel), cert. denied, 111 S. Ct. 1432 (1991); People v. Gordon, 792 P.2d 251, 263-64, 271 (Cal. 1990) (fair trial, prosecutorial misconduct), cert. denied, 111 S. Ct. 1123 (1991); People v. Ramirez, 791 P.2d 965, 981, 984-85 (Cal. 1990) (waiver of right to cross-examination, ineffective assistance of counsel), cert. denied, 111 S. Ct. 1025 (1991); Dahlman v. State Bar, 790 P.2d 1322, 1325 (Cal. 1990) (due process); People v. Miller, 790 P.2d 1289, 1314-15, 1317-18 (Cal. 1990) (prosecutorial misconduct, unfair trial), cert. denied, 111 S. Ct. 713 (1991); People v. Mattson, 789 P.2d 983, 1017-18 (Cal.) (ineffective assistance of counsel), cert. denied, 111 S. Ct. 591 (1990); People v. Clark, 789 P.2d 127, 135-36, 158-59 (Cal.) (voir dire/juror bias, prosecutorial misconduct), modified, 50 Cal. 3d 1157a, cert. denied, 111 S. Ct. 442 (1990); People v. Douglas, 788 P.2d 640, 65153, 674-75, 682 (Cal. 1990) (fair trial, double jeopardy, ineffective assistance of counsel); People v. Lewis, 786 P.2d 892, 907-08 (Cal. 1990) (ineffective assistance of counsel); People v. Thompson, 785 P.2d 857, 874-77 (Cal.) (voluntariness of confession), cert. denied, 111 S. Ct. 226 (1990).

94. State v. White, 785 P.2d 950, 954, 956 (Kan. 1990) (coerced confession; harmless error); State v. Pioletti, 785 P.2d 963, 975, 976 (Kan. 1990) (double jeopardy; prosecutorial misconduct); State v. Graham, 799 P.2d 1003 (Kan. 1990) (admissibility of statements); State v. Wesson, 802 P.2d 574, 581 (Kan. 1990) (double jeopardy), cert. denied, 111 S. Ct. 2866 (1991); State v. Weis, 792 P.2d 989, 991, 992 (Kan. 1990) (seizure); State v. Alires, 792 P.2d 1019, 1022 (Kan. 1990) (suggestive identification); State v. Searles, 793 P.2d 724, 728, 732, 733 (Kan. 1990) (due process; double jeopardy); State v. Probst, 795 P.2d 393 (Kan. 1990) (suppression issue); State v. Bailey, 799 P.2d 977 (Kan. 1990) (validity of stop); State v. Prewett, 785 P.2d 956, 961 (Kan. 1990) (suppression); State v. Toler, 787 P.2d 711, 714, 715 (Kan. 1990) (warrant validity); State v. Jones, 787 P.2d 726, 727 (Kan. 1990) (admissibility of statement); State v. Massey, 795 P.2d 344, 348 (Kan. 1990) (representative jury).

95. State v. Smith, 799 P.2d 497, 501 (Kan. 1990); State v. Massey, 795 P.2d 344, 348 (Kan. 1990); State v. Searles, 793 P.2d 724, 728 (Kan. 1990); State v. Jones, 787 P.2d 726, 728 (Kan. 1990); State v. Toler, 787 P.2d 711, 716 (Kan. 1990); State v. Prewett, 785 P.2d 956, 961 (Kan. 1990).

96. 785 P.2d 956 (Kan. 1990). 
rule announced by the U.S. Supreme Court under the Fourth Amendment, and then said that the standard so announced "has been approved by this court." 97 Otherwise, the case contains no indication as to whether the ruling is one under the state or federal constitution, or both. Of course, one might speculate that the court would have no reason to "approve" a U.S. Supreme Court standard if it were merely applying binding federal law, so the use of this language demonstrates the state constitutional basis of the holding. Things are not that clear, however. The court in Prewett nowhere mentioned the state constitution, nor did it make any Michigan v. Long statement, or use any other kind of language that could be construed as an attempt to insulate the decision from further review. Moreover, although the court cited one of its previous decisions to support its contention that it had adopted the federal standard, that case contains precisely the same ambiguity concerning the basis of the court's ruling as Prewett itself. ${ }^{98}$

\section{Lockstep Analysis}

One reason state courts may fail to specify when constitutional rulings rest on state or federal grounds is that it so often seems not to matter because the two documents have exactly the same meaning they have been interpreted in what is sometimes called "lockstep." 99 For example, in 11 of the 22 Massachusetts cases in which litigants raised both state and federal constitutional claims, the court held that the relevant analysis and result were the same under both constitutions on the facts of the case. Thus, the constitutional standards that will be applied in Massachusetts to some types of due process, ${ }^{100}$ fair trial, ${ }^{101}$ use immunity, ${ }^{102}$ and ineffective assistance of counsel

\section{785 P.2d at 961 .}

98. State v. Walter, 670 P.2d 1354, 1358 (Kan. 1983). To make matters worse, Walter refers approvingly to a prior Kansas lower court decision "adopting" the federal rule. State v. Rose, 665 P.2d 1111 (Kan. Ct. App. 1983). That case, apparently the source of the chain of ambiguity in this line of cases, describes the reason for its ruling as follows:

We have no reason to believe the Kansas Supreme Court would . . . hold that the Kansas Constitution requires Kansas to adopt a rule similar to that in [prior U.S. Supreme Court cases]. Thus, all prior Kansas decisions ... inconsistent with [a very recent Supreme Court case that modified the rule announced in the prior cases] will no longer be followed by this court.

665 P.2d at 1115. It is still unclear from this statement whether Rose is a decision under the federal or state constitution, or both.

99. See Brennan, Bill of Rights, supra note 1, at 550-51; Maltz, supra note 38.

100. Care and Protection of Robert, 556 N.E.2d 993 (Mass. 1990) (standard of proof for loss of custody); Opinion of the Justices, 563 N.E.2d 203 (Mass. 1990) (protection of property interests).

101. Commonwealth v. Gagnon, 557 N.E.2d 728 (Mass. 1990) (right to present evidence).

102. Commonwealth v. Kerr, 563 N.E.2d 1364 (Mass. 1990). 
claims, ${ }^{103}$ as well as to a wide variety of search and seizure issues, ${ }^{104}$ are identical under the state and federal constitutions. Moreover, in another 5 cases adjudicating claims relying solely on the state constitution, the court nevertheless looked to federal law for guidance, and applied an analysis used by federal courts under the federal Constitution. ${ }^{105}$ These cases suggest that participants in the Massachusetts legal system, including the Supreme Judicial Court, have no particular need to distinguish clearly between the state and federal constitutions, because the two documents to a large extent have the same meaning and can thus be used interchangeably.

Much the same is true in other states. In the only 2 Virginia cases explicitly presenting alternative claims under the federal and state constitutions, the court held that the same result obtained under the federal and state constitutions. ${ }^{106}$ Similarly, in 6 Louisiana cases where state and federal constitutional claims were raised separately, the Louisiana Supreme Court held that the relevant analysis and the outcome were the same under both constitutions. ${ }^{107}$

California presents an interesting example of the tendency to interpret state and federal constitutions in lockstep. The California Constitution provides: "Rights guaranteed by this Constitution are not dependent on those guaranteed by the United States Constitution."108 This provision stands as an open invitation to the development of an independent state constitutional jurisprudence. In 1990, there was no sign that this invitation had been taken up: in 14 of the 15 cases where litigants raised both state and federal constitutional challenges to the same government action, the court reached precisely the same result

103. Commonwealth v. Cardenuto, 548 N.E.2d 864 (Mass. 1990).

104. Commonwealth v. Wunder, 556 N.E.2d 65 (Mass. 1990) (probable cause); Commonwealth v. Cast, 556 N.E.2d 69 (Mass. 1990) (exception to warrant requirement); Commonwealth v. Moses, 557 N.E.2d 14 (Mass. 1990) (stop and frisk); Commonwealth v. Tart, 557 N.E.2d 1123 (Mass. 1990) (warrantless administrative search involving request to produce state permit); Commonwealth v. Price, 562 N.E.2d 1355 (Mass. 1990) (standing to challenge search).

105. Commonwealth v. Allen, 549 N.E.2d 430 (Mass. 1990) (probable cause); Commonwealth v. Melendez, 551 N.E.2d 514 (Mass. 1990) (suppression); Commonwealth v. Bray, 553 N.E.2d 538 (Mass. 1990) (retroactivity of decision for purposes of jury instruction); O'Connor v. Police Commr., 557 N.E.2d 1146 (Mass. 1990) (urinalysis); Gauthier v. Police Commr., 557 N.E.2d 1374 (Mass. 1990) (urinalysis).

106. Hess v. Snyder Hunt Corp., 392 S.E.2d 817 (Va. 1990); R.G. Moore Bldg. Corp. v. Committee for the Repeal of Ordinance R(C)-88-13, 391 S.E.2d 587 (Va. 1990).

107. Moresi v. Department of Wildlife and Fisheries, 567 So. 2d 1081 (La. 1990) (existence of civil damages action directly under state constitution for unconstitutional searches and seizures); Paillot v. Wooton, 559 So. $2 \mathrm{~d} 758$ (La. 1990) (procedural due process); State in Interest of J.A.V., 558 So. 2d 214 (La. 1990) (due process/statutory vagueness); State ex rel. Adams v. Butler, 558 So. 2d 552 (La. 1990) (double jeopardy); Gulf States Utils. Co. v. Louisiana Pub. Serv. Commn., 556 So. 2d 573 (La. 1990) (due process); In re Adoption of B.G.S., 556 So. 2d 545 (La. 1990) (due process).

108. CAL. Const. art. I, $\S 24$. 
under both constitutions. This constitutional congruity extended to issues involving the right to a public trial, ${ }^{109}$ the disproportionality of a death sentence, ${ }^{110}$ the right to a representative jury, ${ }^{111}$ juror bias regarding the death penalty, ${ }^{112}$ the right to counsel, ${ }^{113}$ suppression of involuntary confessions, ${ }^{114}$ inadequate assistance of counsel, ${ }^{115}$ due process rights, ${ }^{116}$ the discriminatory use of peremptory challenges, ${ }^{117}$ and the right to confront witnesses. ${ }^{118}$ In 5 additional cases, the court held the state and federal constitutions to have identical meanings by force of the operation of California's Proposition 8, a constitutional amendment dramatically limiting the scope of the state's exclusionary rule. ${ }^{119}$

109. People v. Thompson, 785 P.2d 857, 867-68 (Cal. 1990).

110. People v. Turner, 789 P.2d 887, 916 (Cal. 1990); People v. Marshall, 790 P.2d 676, 691 92 (Cal. 1990).

111. People v. Mattson, 789 P.2d 983, 994-95 (Cal. 1990); People v. Sanders, 797 P.2d 561, 569 (Cal. 1990).

112. Mattson, 789 P.2d at 995-97; Sanders, 797 P.2d at 577.

113. Mattson, 789 P.2d at 1011-13.

114. Marshall, 790 P.2d at 683; People v. Benson, 802 P.2d 330, 343 (Cal. 1990); People v. Gallego, 802 P.2d 169, 201-02 (Cal. 1990). The last case was a pre-Proposition 8 case, so the court held that the state and federal constitutions required the same result on the facts of the case even before Proposition 8 intervened to prevent such an analysis. See infra note 119.

115. Marshall, 790 P.2d at 698-99; In re Fields, 800 P.2d 862 (Cal. 1990).

116. People v. Gonzalez, 800 P.2d 1159, 1172-73 (Cal. 1990); People v. Medina, 799 P.2d 1282, 1288-91 (Cal. 1990); People v. Frank, 798 P.2d 1215 (Cal. 1990); San Diego County Dept. of Social Servs. v. Russell S., 795 P.2d 1244, 1251-53 (Cal. 1990); People v. Jones, 792 P.2d 643, 656-58 (Cal. 1990).

117. People v. Sanders, 797 P.2d 561, 574 (Cal. 1990); People v. Hayes, 802 P.2d 376, 391-92 (Cal. 1990).

118. Frank, 798 P.2d at 1221.

119. People v. Thompson, 785 P.2d 857, 874 (Cal. 1990); People v. Luttenberger, 784 P.2d 633, 639 (Cal. 1990); People v. Prather, 787 P.2d 1012 (Cal. 1990); People v. Douglas, 788 P.2d 640, 654-55 (Cal. 1990); People v. Kelly, 800 P.2d 516, 525-30 (Cal. 1990). Although the results in these cases may be correct, the court's reasoning is almost certainly wrong, and illustrates the degree to which the current California Supreme Court has become attached to federal constitutional law.

Proposition 8, also known as the Victims' Bill of Rights, Prather, 787 P.2d at 1014, was adopted by initiative in 1982. The provision quite simply forbids the exclusion of "relevant evidence" in criminal cases, CAL. CONST. art. I, $\$ 28(d)$; it is, in essence, a constitutional repeal of the state's exclusionary rule. See Wilkes, supra note 6 (arguing that state constitutional amendment process has been used to limit the state constitutional rights of criminal defendants). Of course, so long as the federal Constitution forbids the introduction of some types of evidence, not all evidence of guilt will be admitted, but such exclusions will be the result of federal, not state constitutional restrictions.

Rather than interpreting the proposition to sweep away the exclusionary rule as a matter of state law - its obvious purpose - the court has interpreted it to cut down state constitutional protections only as far as the minimum level of federal protections. In re Lance W., 694 P.2d 744 (Cal. 1985); People v. Luttenberger, 784 P.2d 633 (Cal. 1990). While this will of course be the practical result of any case in which a defendant invokes the exclusionary rule as a matter of state and federal constitutional law, such a result should come about not because both constitutions provide the same protection but because the state constitution provides none and the federal Constitution sets a mandatory floor by operation of the Fourteenth Amendment. $C f$. Collins, supra note 25 , at 15 ("There is no constitutional impediment preventing state courts from grant- 
Like ambiguity regarding the basis of a constitutional ruling, lockstep analysis of the state constitution discourages the development of an independent state constitutional discourse. First, it discourages participants in the legal system from making arguments clearly and distinctly based on the state constitution by reducing the potential benefit from effort invested in developing such an argument. Indeed, because the federal Constitution is generally more fully elaborated than its state counterparts, lockstep analysis tends to elevate federal law into the law of choice for the interpretation of the state constitution; it provides a generous source of off-the-shelf standards and analyses for application to state constitutional problems. Second, lockstep analysis is conducive to the perception that the state constitution is some sort of redundancy - that it is a source of law that has no particular value or purpose and therefore need not be taken seriously. When state constitutional arguments come to be seen as "garbage arguments," 120 the likelihood that litigants or courts will devote much attention to the state constitution is drastically reduced.

Nevertheless, the mere congruity of state and federal constitutional outcomes need not by itself produce these results. The wording of many state constitutional provisions is identical to or closely approximates the wording of corresponding federal provisions, and the historical roots of state constitutions often intertwine with those of the national document; as Chief Justice David Brock of the New Hampshire Supreme Court has noted, certain striking similarities between the construction given the state and federal constitutions are "logical, given their common ancestry."121 In these circumstances, it might well be unremarkable if state and federal constitutional law overlapped to a considerable extent. This possibility underlies in part the appeal of the interstitial approach to state constitutional interpretation: because there is a strong likelihood of doctrinal similarity, it is argued, courts should start with the federal analysis and deviate from it only

ing a lesser degree of protection under state [constitutional] law, provided only that these courts then ... apply ... the federal Constitution ...."). What the court seems to forget is that it is permissible in our system for a state constitution to provide less protection than the U.S. Constitution, as well as more. Indeed, the only case the court decided in 1990 in which it held the state constitution to provide broader protections than the federal Constitution involved application of standards that preceded the adoption of Proposition 8, and which no longer apply in California. People v. Gonzalez, 800 P.2d 1159, 1169 n.3 (Cal. 1990).

120. Abrahamson, supra note 5, at 1162 (quoting Eric Klumb, Comment, The Independent Application of State Constitutional Provisions to Questions of Criminal Procedure, 62 MARQ. L. REV. 596, 620 n.145 (1979)).

121. State v. Pellicci, 580 A.2d 710, 720 (N.H. 1990) (Brock, C.J., concurring); see also Kaye, supra note 5, at 412 ("Common objectives, common drafters and common models naturally engender common texts."). 
for clearly defined reasons. ${ }^{122}$ Yet not even devotees of the interstitial approach suggest that state courts should indiscriminately copy federal analysis into state constitutional law. If state deviations from federal constitutional law may be justified only by textual, historical, or political factors specific to the state constitution, ${ }^{123}$ it follows that doctrinal similarities must be justified by the absence of such factors. Thus, it is not necessarily lockstep interpretation itself that suppresses state constitutional discourse so much as unexplained lockstep interpretation.

Do state courts explain adequately the reasons for lockstep rulings? I suspect that by now the reader will be unsurprised to learn that they do not; in fact, state courts almost never explain the basis for lockstep rulings. For example, the Virginia Supreme Court did not explain the congruity of outcomes in the 2 lockstep cases it decided, except to assert in one case that "we refuse to give any broader interpretation" to the state constitution's due process guarantee. ${ }^{124}$ The Kansas Supreme Court decided 4 cases in lockstep with federal constitutional law; ${ }^{125}$ in none of these cases did the court say much more than that the state constitution affords "the same protections" as, ${ }^{126}$ or is "identical in scope" to, ${ }^{127}$ the federal Constitution. The situation was much the same in New York. In People v. Hernandez, ${ }^{128}$ for example, the court held that the federal and state equal protection clauses produced the same result; the court's only explanation for this congruity was its assertion, without further elaboration, that "no justification for breaking new ground as to [the state] clause . . . is sufficiently advanced." 129

These conclusory rulings do not provide participants in the legal system with any way to recognize situations in which the state constitution should be understood to be similar to the federal Constitution. The litigant who asks why the two documents have the same meaning in a particular case is told by the court, in effect, "they just do." Such

122. See supra notes $43-47$ and accompanying text.

123. See Pollock, supra note 2, at 718-19.

124. R.G. Moore Bldg. Corp. v. Committee for the Repeal of Ordinance R(C)-88-13, 391 S.E.2d 587, 591 (Va. 1990).

125. State v. Wesson, 802 P.2d 574 (Kan. 1990); Love v. One 1967 Chevrolet El Camino, 799 P.2d 1043 (Kan. 1990); State v. Hall, 793 P.2d 737 (Kan. 1990); In re Lucas, 789 P.2d 1157 (Kan. 1990).

126. Lucas, 789 P.2d at 1160 .

127. Love, 799 P.2d at 1048.

128. 552 N.E.2d 621 (N.Y. 1990).

129. 552 N.E. $2 d$ at 624. 
a response makes any kind of further debate about the relative meanings of the state and federal constitutions a virtual impossibility.

\section{Silence on State Constitutional History}

If state constitutional law lacks a discourse of constitutional simi.larity, it also largely lacks a discourse of constitutional distinctness, something that members of the interstitial school of New Federalism hold to be a requirement of proper state constitutional adjudication. ${ }^{130}$ For example, state constitutional history is a factor often cited as a legitimate basis for interpreting state constitutional provisions differently from their federal counterparts, yet state courts almost never resort to the state's constitutional history in the way that federal courts routinely do.

Consider the Massachusetts Constitution, which dates to 1780 and is the oldest continually operative constitution in the United States. ${ }^{131}$ The state constitution was drafted primarily by John Adams, a pivotal figure in the nation's founding, and the author of a treatise on constitutional law that heavily infiuenced thinking about constitutions during the period following independence. ${ }^{132}$ One might expect Adams' views to play a pivotal role in the Massachusetts Supreme Judicial Court's constitutional jurisprudence, and to furnish the basis for divergent interpretations of the state constitution to the extent that Adams' views differed from those of the federal Constitution's Framers. Yet the court has almost never mentioned Adams for any purpose; ${ }^{133}$ indeed, one would never know from reading the court's decisions that the Massachusetts Constitution had any kind of history at all. ${ }^{134}$

As with Massachusetts, the Virginia court has been strangely silent on the state's constitutional history. The Virginia Declaration of

130. See supra note 47 and accompanying text.

131. Sturm, supra note 69 , at 75 .

132. See, e.g., Gordon S. Wood, The Creation of the AMERICAN Republic, 17761787 , at $567-68$ (1969).

133. A computer search of Supreme Judicial Court decisions, unrestricted by date, revealed only six cases in which the court mentioned John Adams, and in most of these the mention is peripheral to resolution of the case. See Commonwealth v. Sheppard, 441 N.E.2d 725, 742 (Mass. 1982) (concurring opinion), revd. sub nom. Massachusetts v. Sheppard, 468 U.S. 981 (1984); Commonwealth v. St. Germain, 408 N.E.2d 1358, 1366 n.18 (Mass. 1980); Commonwealth v. Cundriff, 415 N.E.2d 172, 177 (Mass. 1980); Opinion of the Justices, 309 N.E.2d 476, 480 n.5 (Mass. 1974); Opinion of the Justices, 271 N.E.2d 335, 341 (Mass. 1971); Parker v. Simpson, 62 N.E. 401,407 (1902).

134. In addition to the paucity of references to John Adams, a computer search of Supreme Judicial Court decisions, unrestricted by date, revealed that the court has never mentioned Elbridge Gerry or Rufus King, and has mentioned Samuel Adams only once. Commonwealth v. Nissenbaum, 536 N.E.2d 592, 596 n.5 (Mass. 1989). All were leading figures during the founding period and signers of the Declaration of Independence or federal Constitution. 
Rights was drafted by George Mason, and James Madison later used it as a model for the federal Bill of Rights. One might think that Mason's views would carry some weight in Virginia's construction of its own Declaration of Rights, yet the Virginia Supreme Court appears to have consulted Mason's views only once since $1925^{135}$ - far fewer times than the U.S. Supreme Court has turned to Mason. ${ }^{136}$ Thomas Jefferson's name is similarly missing from the Virginia Supreme Court's jurisprudence. ${ }^{137}$ Like Sherlock Holmes' dog that did not bark in the night, ${ }^{138}$ the court's silence seems significant; the court treats the state constitution, when it treats it at all, like some kind of ahistorical, authorless text. ${ }^{139}$ In so doing, it limits greatly the available ways of talking about the state constitution, thus constraining the scope of any potential state constitutional discourse. ${ }^{140}$

Similarly, Louisiana possesses a unique Spanish and French heritage that could easily account for potentially significant differences between the state and federal constitutions, especially given that it accounts for Louisiana's adherence to the civil law rather than the common law, a feature of the legal landscape shared by no other American state. But the constitutional decisions of the Louisiana Supreme Court give no hint of this unique historical and legal background. Nor is there anything in California state constitutional rulings to suggest that the state was settled under frontier conditions that differed, perhaps significantly, from the conditions under which eastern seaboard states were founded. In short, the state constitutional discourse of distinctness predicted by New Federalism has largely failed to materialize.

\section{B. Exceptions}

Although the general trends in state constitutional law contradict the claims of New Federalism, proponents of New Federalism might

135. Reid v. Gholson, 327 S.E.2d 107, 112 n.10 (Va. 1985). This reference was found by performing a computer search, unrestricted by date, of the opinions of the Virginia Supreme Court contained in a database that includes opinions going back to 1925.

136. Among the many such decisions, see, for example, Welch v. Texas Dept. of Highways \& Pub. Transp., 483 U.S. 468, 483 (1987); Solem v. Helm, 463 U.S. 277, 285-86 n.10 (1983); McDaniel v. Paty, 435 U.S. 618, 629 n.9 (1978); Committee for Pub. Educ. \& Religious Liberty v. Nyquist, 413 U.S. 756, 770 n.28 (1973).

137. An unrestricted computer search of Virginia high court decisions turned up only one relevant reference, and a minor one at that. See Chaves v. Johnson, 335 S.E.2d 97, 102 (Va. 1985) (quoting one short passage from Jefferson's first inaugural address).

138. Pace Marshall J. Tinkle, State Constitutional Law in Maine: At the Crossroads, $13 \mathrm{VT}$. L. REV. 61,67 (1988).

139. I am indebted to my colleague Don Korobkin for this observation.

140. Cf. supra note 69 . 
take comfort from a few exceptions, which I review here for that reason. Occasionally, state courts do diverge from federal law or engage in independent state constitutional analysis. However, even these exceptions often turn out on closer examination to represent less of a departure from the general trends than seems apparent at first glance.

\section{Divergences from Federal Law}

State courts of course do not always interpret the state constitution in lockstep with federal law; occasionally they strike out on their own, a development that New Federalism advocates generally applaud. ${ }^{141}$ The sample surveyed here contains several examples of such divergences. However, the existence of divergent holdings does not necessarily indicate a healthy state constitutional discourse.

Let us return to New York, which again is fairly representative of the sample states as a group. In 1990, the New York Court of Appeals held in 4 cases that the state constitution provides greater protection of individual rights than does the federal Constitution. ${ }^{142}$ Consider People v. Dunn. ${ }^{143}$ There, a criminal defendant challenged a search under the state and federal constitutions. The court began its opinion by analyzing the claim under the Fourth Amendment of the U.S. Constitution, and held that no search had occurred as a matter of federal constitutional law. ${ }^{144}$ Apparently following a more or less interstitial approach, the court then turned explicitly to the state constitutional claim. So far, so good; the court's analysis is systematic, and would clearly be insulated from Supreme Court review under Michigan $v$. Long.

The court framed the relevant state constitutional question as whether it should adopt as a matter of state constitutional law the analysis of the controlling federal case. ${ }^{145}$ The court then pointed out that it had interpreted the state constitution independently from the federal Constitution in the past, and concluded that it would do so

141. See supra note 55 and accompanying text. The existence of state decisions that diverge from federal law seems to be considered a major empirical indicator of state court independence.

142. People v. Dunn, 564 N.E.2d 1054 (N.Y. 1990); People v. Van Pelt, 556 N.E.2d 423 (N.Y. 1990); People v. Vilardi, 555 N.E.2d 915 (N.Y. 1990); People v. Davis, 553 N.E.2d 1008 (N.Y. 1990).

143. 564 N.E.2d 1054 (N.Y. 1990).

144. 564 N.E.2d at $1056-57$.

145. 564 N.E.2d at 1057. This approach should not be confused with a proper interstitial approach to state constitutional interpretation. Proponents of the interstitial approach do not suggest that state courts decide whether a federal rule should be adopted as the state law based on the merits of the federal rule; rather, they urge state courts to adopt whatever rule an independent construction of the state constitution requires, but to do so only when required to reach the state constitutional issue. See supra notes 43-47 and accompanying text. 
again here. ${ }^{146}$ The heart of its analysis is contained in a footnote. "Unlike the Supreme Court," the New York court thought the analysis under the state constitution should have a different "focus" from controlling Fourth Amendment precedent. ${ }^{147}$ The proper focus, it said, was contained in a particular federal circuit court opinion which the New York court found "persuasive." 148 However, the court in no way explained what about this case was persuasive, or why a federal court discussing the federal Constitution should be understood to be saying anything persuasive about the New York Constitution. The New York court went on to cite a dissenting Supreme Court opinion by Justice Brennan, as well as some previously decided New York cases, before concluding that a search had occurred under the state constitutional standard, although the defendant's state constitutional rights had not been violated by that search. ${ }^{149}$

Consider this case for a moment from the perspective of state constitutional discourse. Suppose you are a criminal defense lawyer. Your client was arrested by New York police as the result of a search that is factually distinguishable from the circumstances of Dunn. You want to move to suppress the fruits of the search, and you are quite certain that such a motion will fail under controlling Supreme Court precedent interpreting the Fourth Amendment. When you bring the motion, you therefore include a claim under the New York Constitution which, you argue, provides broader protections to criminal defendants than the Fourth Amendment. In light of Dunn, what kind of an argument can you craft?

Certainly you cannot use Dunn to support any kind of argument suggesting that differences in the text, framers' intent, or founding history of the state constitution justify a different result. Indeed, as far as appears from Dunn, such arguments have not the slightest currency with the Court of Appeals. You can perhaps imitate the winning approach in Dunn by finding old federal lower court cases that went your way before the Supreme Court ruled against the position you advocate, and you may find good language from the dissenters in the relevant Supreme Court cases - but what can you say about these rulings? That they are "persuasive"? Suppose the prosecutor says: "No, they're not persuasive. The majority Supreme Court opinion is much more persuasive." How can you respond?

The truth is, you cannot respond. Although Dunn provides you

146. 564 N.E.2d at 1057.

147. 564 N.E.2d at $1057-58$.

148. 564 N.E.2d at 1058 n.4.

149. 564 N.E.2d at 1058. 
with plenty of ideas for assertions, it provides nothing useful for argument. You can assert that the state constitution is more protective than the Fourth Amendment; you can assert that the New York courts have been willing to depart from federal analyses in the past; you can assert that some case favorable to you is persuasive; but you can neither back up these assertions with arguments if challenged, nor explain why the assertions are relevant to and properly describe your particular case. At bottom, Dunn furnishes the litigant with no language in which to engage in intelligible debate with an opponent or with a judge over the meaning of the state constitution. At best, the participants who want to engage in such a debate - and a criminal defendant may want desperately to do so - can make a series of counterassertions about the meaning of the constitution. But an exchange of conflicting assertions about the constitution does not amount to a meaningful constitutional discourse. ${ }^{150}$

The situation is much the same in Massachusetts. Although the Supreme Judicial Court decided 3 cases in 1990 holding that the state constitution provides broader protection of individual rights than the federal Constitution, ${ }^{151}$ its opinions reveal no intelligible discourse of distinctness on which litigants could rely in order to build effective arguments concerning the ways in which the state and federal constitutions differ.

For example, in Commonwealth v. Amendola, ${ }^{152}$ the court adopted as a matter of state constitutional law the federal Fourth Amendment automatic standing rule, a rule that the U.S. Supreme Court announced in a 1960 case, ${ }^{153}$ but recently abandoned. ${ }^{154}$ The court's only explanation for departing from what appears to be its usual practice of following current federal Fourth Amendment law was that the concerns of the earlier Supreme Court decision "remain valid today,

150. To like effect is People v. Davis, 553 N.E.2d 1008 (N.Y. 1990), another case in which the court diverged from federal holdings. There, the court considered a right to counsel claim under the state and federal constitutions. Although the court held that the New York constitution provided broader protection than the federal, and cited contrasting state and federal cases to prove it, the court never said why or in what way the state constitution provided enhanced protection. 553 N.E.2d at 1010-11. Rather, it simply concluded that the case should come out in a certain way, which is to say that it made an assertion of its own, unsupported by the elements of constitutional discourse to which other participants in the legal system might be able to respond intelligibly. 553 N.E.2d at 1011-13.

151. Commonwealth v. Amendola, 550 N.E.2d 121 (Mass. 1990); Commonwealth v. Melendez, 551 N.E.2d 514 (Mass. 1990); Commonwealth v. Lyons, 564 N.E.2d 390 (Mass. 1990).

152. 550 N.E.2d 121 (Mass. 1990).

153. Jones v. United States, 362 U.S. 257 (1960).

154. United States v. Salvucci, 448 U.S. 83 (1980). 
despite the current Supreme Court's shift in thinking."155 This ruling prompted a dissent from Justice Nolan, who criticized the court for departing from settled federal law "without so much as a plausible argument that the Massachusetts Constitution requires the expansion."156

Amendola provides little basis for participants in the Massachusetts legal system to do much more than make assertions and counterassertions about the meaning of the state constitution; it does not contribute meaningfully to any discourse of constitutional distinctness. And even if the court's language about the "concerns" of a prior federal decision could be parlayed into some kind of debate, there is nevertheless a distinctly hit-or-miss feeling to the court's decisions on whether to adhere to or depart from federal holdings. Thus, in Commonwealth $v$. Cote, ${ }^{157}$ the court said in response to a claim of state constitutional distinctness that the state constitution may "afford more substantive protection" than the federal Constitution, ${ }^{158}$ and found that the issue under scrutiny raised "a closer question" under the state constitution than under the federal, but ended up rejecting the claim of distinctness without any useful explanation. ${ }^{159}$ Likewise, in Commonwealth v. Cast, ${ }^{160}$ the court acknowledged that the state constitution provided "greater protection against unlawful search and seizure" than its federal counterpart, but held against the defendant anyway because the defendant had offered no reason to support his contention that more protection should be available on the facts of the particular case. ${ }^{161}$

Again, these cases are virtually useless from the perspective of state constitutional discourse. There is really no plausible way to look at Amendola, Cote, and Cast and build any kind of intelligible argument about why the Massachusetts Constitution required a departure from the federal approach in one but not the others. Prosecutors and defense counsel can use these cases only to contradict each other, not to debate the meaning of the state constitution.

155. 550 N.E. $2 d$ at 125 .

156. 550 N.E.2d at 127.

157. 556 N.E.2d 45 (Mass. 1990).

158. 556 N.E.2d at 50 (quoting Commonwealth v. Blood, 507-N.E.2d 1029, 1033 n.9 (Mass. 1987)).

159. 556 N.E.2d at 50.

160. 556 N.E.2d 69 (Mass. 1990).

161. 556 N.E.2d at $79,79-80$. 


\section{Independent Analysis}

The cases that most closely support the claims of New Federalism are those in which state courts engaged in true independent analysis of the state constitution using the traditional tools of constitutional interpretation. A potentially promising bright spot is Louisiana, where in a substantial minority of cases the Louisiana Supreme Court approached state constitutional questions more systematically and thoroughly than the cases discussed above. In 81990 cases - nearly $40 \%$ of the total state constitutional cases decided - the court seemed noticeably more willing not only to acknowledge that it was being asked by litigants to construe the state constitution, but actually to honor the request. ${ }^{162}$ The cases in this subset of the court's decisions are not always as thorough or as systematic as they could be, nor do they generally contain the type of Long language necessary to insulate them from further review. Nevertheless, the tone of these opinions suggests that the Louisiana Supreme Court will take state constitutional claims seriously at least some of the time.

For example, in Department of Transportation and Development $v$. Dietrich, ${ }^{163}$ the court considered a question arising under the eminent domain provisions of the state constitution. Although the court's analysis was brief, it included consideration of the text of the relevant provision of the 1974 constitution, that provision's predecessor in the previous constitution, and some judicial precedent relevant to the construction of the provision. ${ }^{164}$ Dietrich thus provides some guidance to participants in the legal system concerning the proper way to talk about the meaning of the constitution; presumably, a litigant will be able in a future case to craft an argument, if one is available, based on the text of a provision of the current constitution and its counterpart in the previous constitution.

In 3 other cases from this group, the court performed something like the type of analysis one might expect to find in a robust constitutional discourse, discussing the text and history of constitutional provisions, the structure of the state constitution, prior state judicial

162. State v. Miller, 571 So. 2d 603 (La. 1990) (double jeopardy); Moresi v. Department of Wildlife \& Fisheries, 567 So. 2d 1081 (La. 1990) (civil remedies for unconstitutional search and seizure); Moore v. Roemer, 567 So. 2d 75 (La. 1990) (judicial jurisdiction); Williams v. Ragland, 567 So. 2d 63 (La. 1990) (judicial retirement); State v. Green, 566 So. 2d 623 (La. 1990) (method of appointing state ethics board); State v. Spellman, 562 So. 2d 455 (La. 1990) (due process); State v. Burrell, 561 So. 2d 692 (La. 1990) (right to notice of aggravating circumstances); Department of Transp. \& Dev. v. Dietrich, 555 So. 2d 1355 (La. 1990) (eminent domain).

163. 555 So. 2d 1355 (La. 1990).

164. 555 So. $2 \mathrm{~d}$ at $1358-59$. 
decisions, and the understanding of the provisions' framers. ${ }^{165}$ The high courts of Kansas, ${ }^{166}$ Massachusetts, ${ }^{167}$ and New York ${ }^{168}$ also decided a small number of cases that treated state constitutional claims with comparable respect.

\section{The California Caseload}

This subsection and the next examine briefly some peculiarities of specific states that make them exceptions of sorts to the general trends outlined in the previous section.

Two unusual aspects of the California Supreme Court's caseload complicate any attempts to generalize about its state constitutional decisions. First, it seems that the majority of the cases in which the California court wrote analytical opinions involved only two kinds of disputes: mandatory death penalty appeals, all of which involved multiple issues of federal and state constitutional law; and attorney discipline cases, of which only a handful involved constitutional issues. Thus, the court's caseload may not provide a representative sample of issues arising under the state constitution.

Second, many if not most of the state constitutional issues facing the court arose from provisions incorporated into the state constitution by popular initiative rather than by constitutional convention or ratification of legislatively proposed amendments. The California Supreme Court has plainly adopted an interpretive approach to such constitutional provisions that treats them more like statutes than constitutional provisions. That is, the court tends to rely heavily on the

165. See Moresi v. Department of Wildlife \& Fisheries, 567 So. 2d 1081 (La. 1990); Moore v. Roemer, 567 So. 2d 75 (La. 1990); Williams v. Ragland, 567 So. $2 d 63$ (La. 1990).

166. See Colorado Interstate Gas Co. v. Board of County Commrs., 802 P.2d 584 (Kan. 1990); Samsel v. Wheeler Transp. Servs., Inc., 789 P.2d 541 (Kan. 1990).

167. See Society of Jesus v. Boston Landmarks Commn., 564 N.E.2d 571 (Mass. 1990); Opinions of the Justices, 556 N.E.2d 1002 (Mass. 1990); Collins v. Secretary of the Commonwealth, 556 N.E.2d 348 (Mass. 1990).

168. See People v. Ohrenstein, 565 N.E.2d 493, $498-99$ (N.Y. 1990) (discussing history and purpose of provision prohibiting use of public money for private undertakings and relying on previous New York cases, some of them very old, to interpret provision); People v. Van Pelt, 556 N.E.2d 423 (N.Y. 1990) (concluding that state constitution provides broader protection of individual rights than federal Constitution and resting conclusion on state standards of fundamental fairness and ethical duties of state prosecutors); People v. Vilardi, 555 N.E.2d 915 (N.Y. 1990) (same); People v. Kern, 554 N.E.2d 1235, 1241 (N.Y. 1990) (examining text of state constitutional provision, comparing it to text of corresponding federal provision, and touching upon understanding of the 1938 constitutional convention that drafted state provision). Other cases in which the court could be considered to have engaged in more considered constitutional analysis are People v. Scalza, 563 N.E.2d 705 (N.Y. 1990) (performing perfunctory constitutional analysis of provision establishing county courts); City of New York v. State, 562 N.E.2d 118 (N.Y. 1990) (construing home rule provision); People v. Bing, 558 N.E.2d 1011 (N.Y. 1990) (construing right to counsel provision); Motor Vehicle Mfrs. Assn. v. State, 550 N.E.2d 919, 923-24 (N.Y. 1990) (construing state court jurisdictional provisions). 
text and what it calls the voters' intent ${ }^{169}$ rather than more "constitutional" factors such as the structure and political theory of, and values expressed in, the document. The court's approach is consistent with and may even be required by the theory of the state constitution, which places restrictions on the types of measures that can be added to the constitution by initiative. ${ }^{170}$ The California Supreme Court is thus sometimes put in the strange position of striking down parts of the state constitution as unconstitutional. ${ }^{171}$ This phenomenon suggests that the state constitution may be viewed as creating two classes of constitutional provisions, some of which are more "constitutional" than others. But whatever the basis of the court's statutory approach to initiative-generated constitutional provisions, the approach limits the types of elements that are likely to enter into the state constitutional discourse.

\section{New Hampshire}

I have saved New Hampshire for last because its state constitutional jurisprudence in several respects departs dramatically from that of the states surveyed above, in ways that make the state a New Federalist's dream. At the same time, though, the court's decisions show that even a court that actively pursues New Federalism's ideals may be unable to escape the imposing shadow of federal constitutional law.

The New Hampshire Supreme Court is a court trying mightily to seize independent control of state constitutional law. First, unlike any of the other courts we have examined, it has consciously developed a habit of making Michigan v. Long statements in its opinions dealing with the state constitution. Thus, the court routinely states specifically that its rulings are made under "our own interpretation of the New Hampshire Constitution," 172 or "as a matter of State law."173 Where the court examines federal constitutional rulings in the course of its state constitutional analysis, it is often at pains to point out that it looks to federal law "not as binding precedent but only for guidance."174 These pronouncements seem more than adequate to insulate the state rulings from federal review.

Second, the court has begun to develop conventions governing the

169. E.g., Davis v. City of Berkeley, 794 P.2d 897 (Cal. 1990).

170. See Raven v. Deukmejian, 801 P.2d 1077 (Cal. 1990).

171. See Raven, 801 P.2d at 1089.

172. State v. Gallant, 574 A.2d 385, 391 (N.H. 1990).

173. State v. Thompson, 571 A.2d 266, 268 (N.H. 1990).

174. State v. Bosquet, 578 A.2d 853, 855 (N.H. 1990); accord State v. Williams, 581 A.2d 78, 80 (N.H. 1990); State v. Gallant, 574 A.2d 385, 391 (N.H. 1990). 
circumstances under which it will construe the state constitution. Most prominently, the court has explicitly stated its intention to adopt a primacy approach to state constitutional claims under which it will adjudicate state constitutional issues before turning to federal ones. ${ }^{175}$ In addition, the court has held that as a general rule it will not consider state constitutional claims unless they were properly raised in the court below. ${ }^{176}$

Finally, the court has proceeded to rest a comparatively large proportion of its constitutional rulings on state grounds. In 1990, the court decided state constitutional issues in $34(24 \%)$ of the 139 full opinions it issued. In 12 of these cases, the court resolved the case on state constitutional grounds without ever considering how it might come out under the federal Constitution. 177 In 8 cases, the court looked to federal law for guidance but ultimately grounded its opinion firmly in the state constitution. ${ }^{178}$ In 4 cases, the court considered parallel claims under the state and federal constitutions where the relevant standards were the same and would have yielded the same outcome, yet deliberately refrained from performing a federal constitutional analysis and instead rested the case exclusively on state constitutional grounds. ${ }^{179}$ And in one additional case, the court held that the state constitution provided greater protection than the comparable federal provision. ${ }^{180}$ Thus, nearly three quarters of the court's state constitutional decisions were based on the state constitution independent of federal law.

175. See State v. Ball, 471 A.2d 347, 351 (N.H. 1983).

176. See State v. Dellorfano, 517 A.2d 1163,1166 (N.H. 1986).

177. State v. Elliott, 585 A.2d 304 (N.H. 1990) (grand jury indictment); Opinion of the Justices, 584 A.2d 1342 (N.H. 1990) (taxation); Lussier v. New England Power Co., 584 A.2d 179 (N.H. 1990) (right to jury trial); State v. Gooden, 582 A.2d 607 (N.H. 1990) (double jeopardy); In re Estate of McQuesten, 578 A.2d 335 (N.H. 1990) (takings and due process); State v. Eason, 577 A.2d 1203 (N.H. 1990) (rights to produce evidence and to confront); Appeal of Maddox, 575 A.2d 1 (N.H. 1990) (impartial administrative decisionmaker); State v. Monsalve, 574 A.2d 1384 (N.H. 1990) (due process); New Hampshire Mun. Trust Workers' Compensation Fund v. Flynn, 573 A.2d 439 (N.H. 1990) (local government funding); Kiluk v. Potter, 572 A.2d 1157 (N.H. 1990) (state court jurisdiction); State v. Lachapelle, 572 A.2d 584 (N.H. 1990) (notice of criminal charges); State v. Smith, 571 A.2d 279 (N.H. 1990) (right to bear arms, procedural due process).

178. State v. Williams, 581 A.2d 78 (N.H. 1990) (right to jury trial); State v. Pellicci, 580 A.2d 710 (N.H. 1990) (searches); State v. Bousquet, 578 A.2d 853 (N.H. 1990) (right to jury trial); In re Certain Scholarship Funds, 575 A.2d 1325 (N.H. 1990) (equal protection); Dover v. Imperial Casualty \& Indem. Co., 575 A.2d 1280 (N.H. 1990) (equal protection); State v. Gallant, 574 A.2d 385 (N.H. 1990) (searches); State v. Field, 571 A.2d 1276 (N.H. 1990) (exclusionary rule); State v. Thompson, 571 A.2d 266 (N.H. 1990) ("knock-and-announce" rule).

179. State v. Bousquet, 578 A.2d 853 (N.H. 1990) (right to jury trial); In re Certain Scholarship Funds, 575 A.2d 1325 (N.H. 1990) (equal protection); State v. Green, 575 A.2d 1308, 1315 (N.H. 1990) (searches); State v. Settle, 570 A.2d 895, 897 (N.H. 1990) (sufficiency of indictment).

180. State v. Pellicci, 580 A.2d 710 (N.H. 1990) (holding canine sniff a search under state constitution). 
Yet even in this New Federalism paradise, all is not entirely well. For example, despite its attempts to distinguish clearly between state and federal constitutional claims, the New Hampshire Supreme Court has sometimes fallen prey to the same kinds of obscurities we have seen in the decisions of other state high courts. Thus, in 4 cases the court failed to specify whether the constitutional claim under consideration was a state or federal claim, ${ }^{181}$ and in 8 cases both federal and state constitutional claims were raised but the basis of the court's ruling was unclear. ${ }^{182}$

A much more fundamental problem with the court's state constitutional jurisprudence, however, is that its independence is ultimately illusory. The court has held explicitly that the state and federal constitutions have essentially the same meaning in a variety of circumstances involving issues such as probable cause, interrogations, due process, and ineffective assistance of counsel. ${ }^{183}$ Moreover, in many instances where the court has expressly asserted decisional independence under state law, the language and structure of its analyses of the state constitution are quite clearly borrowed from federal constitutional law. ${ }^{184}$ For example, the state constitution's equal protection analysis and terminology is precisely the same as the federal, ${ }^{185}$ even if the state and federal courts might not always agree on the applications of the relevant tests. Together, these types of cases account for nearly half of the court's state constitutional caseload.

Most importantly, notwithstanding whatever legal independence the court may have achieved from federal constitutional law, it has failed to achieve any kind of independence in its constitutional discourse. For all its talk of independence, the New Hampshire Supreme Court rarely decides a case without keeping one eye on the comparable decisions of the U.S. Supreme Court. In addition, the New Hampshire court's opinions are largely devoid of any kind of language that could

181. State v. Zurita, 584 A.2d 758 (N.H. 1990) (confessions); State v. Plante, 577 A.2d 95 (N.H. 1990) (confessions); State v. Green, 575 A.2d 1308 (N.H. 1990) (challenge to stop); Kakris v. Montbleau, 575 A.2d 1293 (N.H. 1990) (due process).

182. State v. Pond, 584 A.2d 770 (N.H. 1990) (double jeopardy); Bussiere v. Cunningham, 571 A.2d 908 (N.H. 1990) (due process liberty); Humphrey v. Cunningham, 584 A.2d 763 (N.H. 1990) (ineffective assistance of counsel); State v. Fennell, 578 A.2d 329 (N.H. 1990) (ineffective assistance of counsel); State v. Cox, 575 A.2d 1320 (N.H. 1990) (right to present exculpatory evidence); State v. Green, 575 A.2d 1308 (N.H. 1990) (interrogation); State v. Tucker, 575 A.2d 810 (N.H. 1990) (suppression); State v. Davis, 575 A.2d 4 (N.H. 1990) (probable cause). In all but the first two of these cases, the court held that the applicable analysis was the same under either constitution, but failed to specify whether the basis of its holding was the state or federal constitution, or both. In none of the cases did the court make a Long statement.

183. See the last six cases cited supra note 182.

184. See supra note 178.

185. E.g., In re Certain Scholarship Funds, 575 A.2d 1325, 1326-27 (N.H. 1990). 
furnish the basis for a discourse of distinctiveness - a way of explaining differences between the state and federal constitutions. The current New Hampshire Constitution has been in effect since 1784, and it is hardly implausible that small, relatively isolated New Hampshire could have developed over the past two centuries some kinds of cultural and political differences from the rest of the nation that would show up in its constitutional discourse and jurisprudence. Yet one searches the state court's decisions in vain for any indication of such differences; there is no discussion of the state's founding history, no mention of its constitution's framers, and no suggestion that the fundamental values or character of the people of the state differ in any way from those of the people of the nation.

\section{Conclusions}

The overwhelming impression left by an examination of state constitutional decisions is that state courts by and large have little interest in creating the kind of state constitutional discourse necessary to build an independent body of state constitutional law. With a handful of exceptions, the decisions fail to address state constitutional issues squarely and independently from federal constitutional jurisprudence, and show no sign of any discourse of distinctness that would allow participants in the legal system to craft intelligible arguments about the nature of any differences between the state and federal constitutions.

By engaging in extensive lockstep analysis, many courts have also created an atmosphere in which it is unnecessary to distinguish between the state and federal constitutions because they are generally held to have the same meaning. This reduces state constitutional law to a redundancy and greatly discourages its use and development. In the few cases in which courts hold the state and federal constitutions to be distinct, they often seem to have done so in a way that is so idiosyncratically result-oriented as to provide little basis for further intelligible debate about the nature of the differences between the two documents that account for the court's departures from federal norms. Certainly, litigants can hardly be confident about replicating the results of such cases in factually distinct circumstances.

Furthermore, the lesson of Michigan v. Long seems not to have penetrated the jurisprudence of any state other than New Hampshire. By failing to specify when holdings rest on state constitutional grounds and by borrowing extensively from federal case law when construing their state constitutions, state courts not only confuse participants in the state legal system but also leave themselves highly vul- 
nerable to Supreme Court review of decisions that may rest on adequate and independent state grounds.

When he was still on the Oregon Supreme Court, Hans Linde complained that "[a] generation of lawyers . . . seems literally speechless" when faced with questions of state constitutional law. ${ }^{186}$ In view of the actual condition of state constitutional law, however, such silence seems understandable enough when lawyers lack a language in which to speak, or at best have a language that is too impoverished to allow them to say anything worthwhile. ${ }^{187}$

\section{The StANDARd EXPLANATIONS}

We have seen that state constitutional discourse is for the most part far from the vigorously independent discourse New Federalism hoped for; it is impoverished by comparison to federal constitutional discourse, and it generally fails to provide a language that participants in the legal system can use effectively to debate the meaning of the state constitution. State courts often seem downright reluctant to construe their state constitutions at all, and when they do so their opinions are often vague, perfunctory, or almost entirely dependent on analytic strategies and terminology borrowed from federal constitutional discourse.

Why should this be the case? Why, after more than two centuries of state constitutionalism, has state constitutional law so spectacularly failed to flourish? Advocates of New Federalism have come up with several standard and widely accepted explanations for this phenomenon. In this section, I review these explanations, and argue that they fail to account for the poverty of state constitutional discourse.

\section{A. The Fourteenth Amendment}

By far the most widely accepted explanation for the poverty of contemporary state constitutional law holds that it was marginalized by the Fourteenth Amendment incorporation doctrine. Until the early part of this century, the U.S. Supreme Court adhered to the view that the federal Bill of Rights constrained only the federal government; any similar restrictions on state government, if they existed, were contained in state constitutions. ${ }^{188}$ Starting in the 1930s, however, and continuing into the 1960 s, the Supreme Court began to inter-

186. Linde, supra note 30 , at 391.

187. For a different view of the constitutional jurisprudence of the New York Court of Appeals, see Vincent M. Bonaventre, State Constitutionalism in New York: A Non-Reactive Tradition, 2 EMERging Issues IN ST. CoNst. L. 31 (1989).

188. Barron v. Mayor of Baltimore, 32 U.S. (7 Pet.) 243 (1833). 
pret the Fourteenth Amendment as incorporating many of the standards contained in the Bill of Rights as limitations on state power. ${ }^{189}$

Proponents of what I shall call the "Fourteenth Amendment thesis" argue that the process of incorporation "federalized" the business of interpreting constitutional rights. ${ }^{190}$ By making states enforce federal constitutional standards, ${ }^{191}$ incorporation "obscured the functional independence" of state courts, ${ }^{192}$ and required state courts to look to federal law in order to resolve a wide variety of constitutional issues. As a result, the argument goes, state courts have simply gotten into the habit of looking to federal constitutional law for the answer to constitutional questions, whether state or federal. ${ }^{193}$

This explanation is wholly inadequate; indeed, it is not an explanation of state court behavior at all, but rather a description of such behavior. Under our system of government, states are independent sovereigns and state supreme courts are the final arbiters of constitutional self-government on the state level. In the early days of the republic, state courts often jealously guarded against any perceived federal encroachments on state sovereignty and independence. In Martin v. Hunter's Lessee, ${ }^{194}$ for example, the Virginia courts rejected the authority of the Supreme Court to review state court decisions on federal law; the Supreme Court thus had to struggle with state courts over what now seem some of the least controversial aspects of constitutional federalism.

While we no longer expect state courts to resist rulings that the Supreme Court is entitled to make and enforce, we might well expect state courts to continue to protect state sovereignty and independence where it is possible to do so. Had state courts in the middle decades of this century been animated by such a spirit, there was certainly nothing stopping them from staving off the federal dominance in constitutional rights brought about by the Supreme Court's incorporation decisions. For example, state courts could have utilized their state

189. See generally LAURENCE H. TRIBE, AMERICAN Constitutional LAW $772-74$ (2d ed. 1988).

190. E.g., Kaye, supra note 5, at 404-05; Linde, supra note 30, at 382-83; Gary L. McDowell, Foreword: Rediscovering Federalism? State Constitutional Law and the Restoration of State Sovereignty, 21 RUTGERS L.J. 797, 802-07 (1990).

191. Brennan, State Constitutions, supra note 1, at 495.

192. Developments in the Law, supra note 43, at 1328.

193. See Howard, supra note 25, at 878 ("During the activist Warren years, it was easy for state courts ... to fall into the drowsy habit of looking no further than federal constitutional law."); accord Project Report, supra note 25, at 274.

194. 14 U.S. (1 Wheat.) 304 (1816). 
constitutions before the Supreme Court began its string of incorporation decisions, thereby preventing the Court from gaining the impression that states would not protect the fundamental rights of U.S. citizens unless forced to do so by the imposition of federal constitutional standards. ${ }^{195}$ Or, upon perceiving a threat to state sovereignty, state courts could have seized the initiative in elaborating constitutional rights by giving generous interpretations to their state constitutions, something they did not even begin to do until recently, when it was probably too late. The real question is thus not whether incorporation changed the constitutional landscape, but why state courts did nothing to influence the final result. ${ }^{196}$

Furthermore, even if the Fourteenth Amendment thesis could explain the withering of state constitutional jurisprudence in the area of individual rights, it has no power to explain the current extent to which federal constitutional discourse dominates state constitutional law. It is useful here to distinguish between two types of state constitutional provisions. Dependent provisions are provisions of the state constitution that have federal analogues capable of controlling the outcome of cases in which both provisions apply. For example, a state search and seizure provision is dependent because it has a federal analogue - the Fourth Amendment - capable of controlling the outcome of the case, depending on the interpretation the federal courts have given it. An independent state constitutional provision is one that cannot be displaced, regardless of whether an analogous federal constitutional provision exists. For example, a state constitutional provision governing executive power is independent because the state court's construction of that provision will define the extent of the governor's power regardless of how the Supreme Court interprets the powers of the President under the federal Constitution.

The Fourteenth Amendment thesis could at best explain why federal constitutional discourse has come to dominate the state constitu-

195. State courts arguably had such poor records of protecting the fundamental rights of their citizens, see supra note 29, that there was nothing for the Fourteenth Amendment to marginalize.

196. A variation of the Fourteenth Amendment thesis holds that state courts failed to develop independent state constitutional law because they were literally "too busy" keeping up with rapidly changing federal constitutional law to pay much attention to their own constitutions. See DeVelopments in STATE Constitutional Law, supra note 7, at 4; A.E. Dick Howard, $A$ Frequent Recurrence to First Principles, Introduction to id., at xi, xv. It is surprising that such an argument could be seriously advanced. Nobody has claimed that state courts failed to continue developing state common law during this period because the constitutional decisions of the Supreme Court kept them too busy. Nor is there any evidence that lower federal courts had the slightest difficulty "keeping up" with the Supreme Court's constitutional rulings. Indeed, the Supreme Court incorporation cases could just as easily be viewed as saving time for state courts by providing vivid demonstrations of the proper way to interpret a constitution. 
tional discourse of dependent provisions of state constitutions. If the outcome of a state constitutional case dealing with free speech or involuntary confessions turns in the final analysis on whether any standard set by the state constitution satisfies the demands of the controlling federal constitutional provision, ${ }^{197}$ state courts might develop a tendency to use the terms of the federal discourse even when discussing the state constitutional issue. In reality, however, state courts have adopted the federal analysis and terms of debate not merely when construing dependent provisions governed by Fourteenth Amendment incorporation, but also for many independent state constitutional provisions that federal law - as incorporated in the Fourteenth Amendment - is powerless to affect.

Consider, for example, the political question doctrine. The doctrine, a judicial gloss on the jurisdictional provisions of Article III of the federal Constitution, holds that federal courts may not hear certain types of cases for which the exercise of judicial power is deemed inappropriate. ${ }^{198}$ Typically, the doctrine is invoked in instances where the Supreme Court would conceive itself to be meddling in the legitimate affairs of other branches of government; for example, the doctrine applies to cases in which the court lacks expertise or which involve the exercise of a power constitutionally committed to the executive or legislative branches. ${ }^{199}$ Several state supreme courts have held that state court jurisdiction is limited by a state version of the federal political question doctrine, and some courts have more or less expressly incorporated the leading federal cases into the state's political question jurisprudence. ${ }^{200}$

Now it is certainly possible for a state constitution to contain a political question doctrine, and it is even possible for the state doctrine to be so similar to the federal version that precisely the same analysis could be used for both - possible, but highly unlikely. Unlike the federal courts, which are courts of limited jurisdiction, state courts

197. See U.S. ConsT. art. VI, cl. 2; amend. 14.

198. The leading case is still Baker v. Carr, 369 U.S. 186, 217 (1962). See also Goldwater v. Carter, 444 U.S. 996, 998-1000 (1979) (Powell, J., concurring).

199. Baker, 369 U.S. at 217.

200. See Pellegrino v. O'Neill, 480 A.2d 476, 481-83 (Conn. 1984); State ex rel. Oberly v. Troise, 526 A.2d 898, 904-05 (Del. 1987); Trustees of Hawaiian Affairs v. Yamasaki, 737 P.2d 446, 455-56 (Haw. 1987); Kluk v. Lang, 531 N.E.2d 790, 797 (I11. 1988); Gilbert v. Gladden, 432 A.2d 1351, 1354 (N.J. 1981); State ex rel. Meshel v. Keip, 423 N.E.2d 60, 64 (Ohio 1981); People v. Ohrenstein, 549 N.Y.S.2d 962, 971 (App.Div. 1989), affd. on other grounds, 565 N.E.2d 493 (N.Y. 1990) (adopting Baker analysis). Other cases are collected in Nat Stern, The Political Question Doctrine in State Courts, 35 S.C. L. REv. 405 (1984). 
may be courts of general jurisdiction. ${ }^{201}$ In the absence of limiting constitutional language, the ordinary presumption would be that state courts are constitutionally empowered to hear cases, not that they share a limitation in common with federal courts. ${ }^{202}$ Further, virtually all state courts have significant common law powers that federal courts lack. The power to elaborate the common law is a power to make law, and to do so in what are nowadays extremely complex areas such as tort liability and contractual relations. The political question doctrine, however, is based on the incompetence of federal courts to invade the legislative sphere, or to deal with complex aspects of social policy - actions that state courts take routinely when exercising their common law powers. Thus, it is not at all clear that state courts should be subject to a political question limitation, and if they are, it seems implausible that the state limitation would be nearly so restrictive as the federal one. ${ }^{203}$

Similarly, several state supreme courts have adopted the federal interpretation of the Speech or Debate Clause ${ }^{204}$ and the federal separation of powers bar on the legislative veto, ${ }^{205}$ both aspects of state constitutional law that might be expected to differ, perhaps significantly, from their federal counterparts. ${ }^{206}$ The Fourteenth Amend-

201. Scott v. Sandford, 60 U.S. (19 How.) 393, 401-02 (1857); Aldinger v. Howard, 427 U.S. 1,15 (1976).

202. This phenomenon can be seen clearly in state law dealing with standing. Many states have far more relaxed rules of standing than federal courts due to the unrestricted jurisdiction of state courts. See generally Jennifer Friesen, Recovering Damages for State Bills of Rights Claims, 63 TEXAS L. REV. 1269, 1298-303 (1985). Others permit their courts to issue advisory opinions, something federal courts are forbidden to do because of the lack of a case or controversy. U.S. ConsT. art. III, \& 2, cl. 1; see Charles M. Carberry, Comment, The State Advisory Opinion in Perspective, 44 Fordham L. ReV. 81 (1975).

203. Cf. Dennis NettikSimmons, Towards a Theory of State Constitutional Jurisprudence, 46 MONT. L. REV. 261, 285 (1985).

204. U.S. CoNST. art. I, § 6, cl. 1 .

205. See INS v. Chadha, 462 U.S. 919 (1983).

206. For example, a state version of the Speech or Debate Clause might differ from the federal version because state legislatures, unlike Congress, have the direct power to pass legislation insulating themselves from liability under state law for statements made or things done in the course of their legislative duties. In addition, state courts have the power to create exceptions to common law doctrines, such as libel, for such public policy reasons as immunizing legislators in appropriate situations. These factors might suggest an extremely narrow reading for a state Speech or Debate Clause on the theory that the state legislature or courts can always broaden the scope of legislative immunity.

Similarly, there is no good reason to assume that the legislative veto would be unconstitutional under a state constitution. The Supreme Court invalidated the use of legislative vetoes on separation of power grounds, INS v. Chadha, 462 U.S. 919 (1983), but the structure of separation of powers under state constitutions often differs dramatically from the federal division of power. For example, governors often have line-item veto powers; courts often have lawmaking and rulemaking powers; and lower-ranking executive branch officials, such as attorneys general and comptrollers, are often independently elected. Given these differences, it does not necessarily follow that the separation of powers means the same thing under a state constitution as under the U.S. Constitution. 
ment thesis fails to explain the willingness of state courts to adopt federal doctrine in these areas in which state constitutional law operates completely independently of federal power.

\section{B. Lawyers and Law Schools}

The second most popular explanation for the languishing of state constitutional law offered by New Federalism advocates is that lawyers who appear in state court fail to raise independent state constitutional arguments. ${ }^{207}$ Some have added that the fault really lies with the law schools, which fail to teach state constitutional law. ${ }^{208}$ This finger-pointing, which seems especially popular with state judges, ${ }^{209}$ is occasionally accompanied by a disapproving suggestion of lawyer laziness: "[T]o make an independent argument under the state [constitution]," former Justice Hans Linde has admonished, "takes homework - in texts, in history, in alternative approaches to analysis."210

The suggestion that lawyers are somehow responsible for the failure of state courts to develop state constitutional jurisprudence is frankly absurd. Lawyers will make the arguments they need to make to win cases. If lawyers are not making state constitutional arguments, it is because doing so does not help them win. ${ }^{211}$ As the survey of state constitutional cases in the previous section shows, state courts often discourage the making of such arguments by their own adjudicatory practices.

As for law schools, it is undoubtedly always popular to blame them for ills of the legal system, and sometimes such blame may be justified - but not in this case. It is true that few law schools offer courses in the constitutional law of particular states; but it is equally true that few law schools offer courses in the contract, tort, or property law of particular states. Somehow law school graduates are able to work effectively within the state common law systems after a legal education in general principles of those areas of law, and constitutional law is no different. The real problem is not the education in

207. Abrahamson, supra note 5, at 1161-63; Collins, supra note 25, at $19 \mathrm{n.69}$; James C. Kirby, Jr., Expansive Judicial Review of Economic Regulation Under State Constitutions, in DEVELOPMENTS IN STATE CONSTTTUTIONAL LAW, supra note 7, at 94, 94-95; Linde, supra note 30, at 391-92; Pollock, supra note 2, at 721-22; Collins, supra note 29, at 9 \& n.75.

208. Abrahamson, supra note 5, at 1163; Abrahamson, supra note 29, at 964; Douglas, supra note 29, at 1147; Kaye, supra note 5, at 405; Linde, supra note 30, at 392; Linde, supra note 5, at 174-75; Collins, supra note 29, at 5-6.

209. See the articles by Judge Judith Kaye, supra note 5, former Justice Hans Linde, supra notes 5 and 30, Justice Shirley Abrahamson, supra notes 5 and 29, and Justice Charles G. Douglas, III, supra note 29.

210. Linde, supra note 30 , at 392.

211. Abrahamson, supra note 5, at 1162-63. 
state constitutional law offered by law schools, but the one offered by state courts.

\section{Lack of Historical Data}

A third explanation sometimes given for the impoverishment of state constitutional law is the dearth of historical materials related to the founding of the state constitution. ${ }^{212}$ The lack of such materials can hinder the search for constitutional meaning by making it extremely difficult to reconstruct the intent of the framers, thereby hindering the development of an independent state constitutional discourse and making the turn to federal analogues more appealing. This is a cogent explanation, but, as it turns out, one available to very few states.

Among the fifty states, only Massachusetts, Vermont, and New Hampshire now operate under constitutions adopted in the eighteenth century. ${ }^{213}$ The present constitutions of eighteen states were adopted after 1900, and fifteen states operate under constitutions that were adopted between 1875 and 1899.214 The recency of these documents greatly enhances the possibility of meaningful historical research. Moreover, even the older constitutions have been amended so often that the adoption of many significant constitutional provisions is likely to be well recorded.215 And even where recordkeeping at constitutional conventions was skimpy, other sources such as newspaper accounts and the personal correspondence of delegates can help fill in the historical gaps. Work by Justice Robert F. Utter of the Washington Supreme Court illustrates the type of creative historical research that can be done in this area. ${ }^{216}$

Finally, detailed historical records are simply not necessary to create a rich constitutional discourse. Chief Justice John Marshall lacked many of the historical sources that are readily available to and routinely consulted by judges and lawyers today, ${ }^{217}$ yet he managed none-

212. See, e.g., Teachout, supra note 28.

213. Sturm, supra note 69 , at $75-76$.

214. Id. at 74-76.

215. Grodin, supra note 54, at 393-95 (discussing documentation of 1849 California constitutional convention); Vito J. Titone, State Constitutional Interpretation: The Search for an Anchor in a Rough Sea, 61 ST. JoHN's L. REv. 431, 459-63 (1987).

216. See Utter, supra note 35, at 253-59; Robert F. Utter, Church and State on the Frontier: The History of the Establishment Clauses in the Washington State Constitution, 15 Hastings CONST. L.Q. 451 (1988).

217. For example, James Madison's notes of the constitutional convention were not published until 1840, after his death. See James Madison, Notes of Debates IN THE FEDERAL Convention of 1787 viii-ix (Adrienne Koch ed., 1966). 
theless almost single-handedly to found the rich and intricate federal constitutional discourse that we have inherited.

\section{The Failure of State Constitutionalism}

If none of the reasons examined above explains the poverty of modern state constitutional discourse, what can explain it? In this Part, I argue that the cause of the problem is a failure that goes much deeper than the actions of the Supreme Court, the state bar, or the law schools. All these groups, as well as state courts themselves, are responding to the same underlying phenomenon: the failure of state constitutionalism itself to provide a workable model for the contemporary practice of constitutional law and discourse on the state level. In particular, state courts do not talk about state constitutions in the way New Federalism advocates because to do so would be to talk in a way that, under present conditions, simply makes no sense.

\section{A. State Constitutionalism}

State constitutionalism lies at the intersection of two powerful American political doctrines: federalism and constitutionalism. Federalism provides a theory of statehood, constitutionalism a theory of the nature of constitutions. Together, these two sets of principles provide a guiding, foundational approach to the interpretation of state constitutions, an approach that has decisively shaped the thinking of New Federalism advocates, as well as state courts themselves.

\section{Federalism}

The fundamental organizing principle that distinguishes states from other political entities in our system of government is the familiar notion of federalism. According to federalist doctrine, the United States is a unique kind of republic composed of individual state governments and a single, overarching national government. Although the states are "constituent parts" of the United States, ${ }^{218}$ they are not in any essential way subordinate to the national government. Rather, the state and national governments together comprise a system of dual sovereignty ${ }^{219}$ in which each government is deemed to be an independent sovereign, but in distinct spheres of action. ${ }^{220}$ Madison, for example, conceived that the national government would have primary

218. The Federalist, supra note 37, No. 9 (Alexander Hamilton), at 76.

219. Raoul Berger, Federalism: The Founders' Design 48-76 (1987).

220. The Federalist, supra note 37, No. 39 (James Madison), at 244; see David F. EpSTein, The Polmtical Theory of The Federalist $51-52$ (1984). 
responsibility for "external objects, as war, peace, negotiation and foreign commerce"; the states, on the other hand, would exercise sovereignty principally over "the lives, liberties, and properties of the people."221

At the time of the framing of the Constitution, there was some disagreement over the idea of dividing governmental sovereignty in this way; some thought that sovereignty was by its nature indivisible, and that any attempt to divide it must fail. The Framers solved this theoretical difficulty by locating a single, indivisible sovereignty in the people themselves. As ultimate sovereign, the people could divide up the powers of government and distribute them as they saw fit.222 Thus, according to Madison, "The federal and State governments are in fact but different agents and trustees of the people, constituted with different powers and designed for different purposes."223

Under this plan, the people have organized themselves for purposes of self-government in the following way. First, all the people of the United States together constitute a society that has created and is jointly subject to the rule of the national government within its designated scope. Second, the people have divided themselves into separate, smaller societies - the states - and are subject in this second capacity to the rule of the government of the state in which they reside.224 Every citizen thus belongs to two distinct political societies, each constituted for a different purpose and having different powers and characteristics.

In this way, federalism provides a clear political definition of statehood. ${ }^{225}$ According to federalist doctrine, a state is a self-governing political society of individuals who comprise a subset of all American citizens. The state government is created by the people of the state and given such powers as the people deem appropriate, other than those specifically delegated to the United States, another self-governing society to which the people of the state also belong. The state government thus possesses whatever independent sovereign power the

221. The FeDERAlist, supra note 37, No. 45, at 292-93; see also id. No. 39 (James Madison), at 245 (states would exercise "a residuary and inviolable sovereignty over all other objects" not put within power of national government).

222. See BERGER, supra note 219, at 51-52 (remarks of James Wilson).

223. The Federalist, supra note 37, No. 46, at 294.

224. See The Federalist, supra note 37, No. 39 (James Madison), at 245.

225. Federalism's political premises rest on other philosophic considerations that are not directly relevant here, such as Enlightenment era epistemology and related theories of natural law. For a survey of these ideas, see Morton White, Philosophy, The Federalist, and THE CONSTITUTION (1987). For a more complete discussion of the contours of the doctrine of popular sovereignty, see James A. Gardner, Consent, Legitimacy and Elections: Implementing Popular Sovereignty Under the Lockean Constitution, 52 U. PrTT. L. REv. 189, $200-13$ (1990). 
people of the state choose to give it, within the potential realm of activity allowed it by the national political society.

\section{Constitutionalism}

The other half of the state constitutionalism equation is the notion of constitutionalism - the idea that a constitution is a unique document of political foundation. Like federalism, constitutionalism is close to the heart of American political theory and rests on many of the same political premises.

The pithiest, although by no means the first, expression of the essence of American constitutionalism is Chief Justice John Marshall's remark in McCulloch v. Maryland:226 "[W] must never forget," he wrote, "that it is a constitution we are expounding."227 This cryptic phrase aptly captures the judicial view, embraced consistently ever since, that a constitution is different from other types of documents that courts may be called upon to interpret and must be approached at all times with those differences in mind.

The first and foremost difference between a constitution and other sources of law is that a constitution is considered to be a direct act of the sovereign people themselves. ${ }^{228}$ Because the people are the sovereigns in our system and the government merely the people's agents, a constitution speaks with a political authority that no law or other governmental action can ever attain. The constitution is thus a form of higher law that always binds the government, and is unchangeable except by further action of the people themselves. ${ }^{229}$ That a constitution is written only further evidences the people's intent that it be permanent.

But it is not only the authority of a constitution that distinguishes it from other forms of law; it differs in subject matter as well. A constitution is a charter of self-government; it is the means by which the people communicate to their agents the scope of authority that may be wielded in the people's behalf. ${ }^{230}$ As a result, according once again to Chief Justice Marshall, the nature of a constitution "requires, that only its great outlines should be marked, [and] its important objects

226. 17 U.S. (4 Wheat.) 316 (1819).

227. 17 U.S. (4 Wheat.) at 407. 13.

228. See, e.g., U.S. ConST. pmbl. ("We the People ... "); Gardner, supra note 225, at 200.

229. See, e.g., Raoul Berger, Death Penalties 66 (1982); Henry Monaghan, Our Perfect Constitution, 56 N.Y.U. L. REv. 353, 376 \& n. 135, 392 (1981); Earl Maltz, Foreword: The Appeal of Originalism, 1987 UTAH L. REV. 773, 801-02.

230. Cf. The Federalist, supra note 37, No. 10 (James Madison), at 82; No. 2 (John Jay), at 37 ; No. 46 , at 294; No. 78 (Alexander Hamilton), at 467. 
designated."231 To use the current language of the Supreme Court, the Constitution embodies the "fundamental values" of the American people. ${ }^{232}$

Although these principles of constitutionalism are most often associated with the U.S. Constitution, they are generally thought to apply with equal force to state constitutions. The only difference is that the federal Constitution is thought to express the fundamental values and choices of the national polity, and state constitutions are thought to express the fundamental values of the various state polities that have adopted them. Thus, many state supreme courts use the language of "fundamental values" when construing their state constitutions;"233 as Judge Judith Kaye of the New York Court of Appeals has written, the state constitution is "that set of values to which we have bound ourselves, the values that transcend even our currently made choices."234

\section{Constitutionalism and Constitutional Discourse}

In addition to their political dimensions, constitutionalism and federalism also suggest a way of thinking about the community-defining aspects of constitutional discourse. Because a constitution is a document that by definition embodies the most fundamental decisions of a polity concerning the ways in which its members want to live their lives, a constitution necessarily reveals a wealth of information about the character of those who, politically speaking, are its authors. ${ }^{235}$ To place instructions in a constitution is to say that certain things shall or shall not be done, and to constrain the actions of the government in this way is to say that we are a people who will not tolerate (or who require) certain types of behavior toward one another. The content of a constitution can thus reflect some of the most essential and intimate

231. $\mathrm{McC}$ Culloch, 17 U.S. (4 Wheat.) at 407.

232. See, e.g., Thornburgh v. American College of Obstetricians \& Gynecologists, 476 U.S. 747,789 (1986) (White, J., dissenting) ("The Constitution . . . is a document announcing fundamental principles in value-laden terms"); In re Winship, 397 U.S. 358, 372 (1970) (Harlan, J., concurring) (Constitution embodies "fundamental value determination of our society that it is far worse to convict an innocent man than to let a guilty man go free"); Spaziano v. Florida, 468 U.S. 447, 471 (1984) (Stevens, J.) (Eighth Amendment reflects "a fundamental value that the Framers wished to secure against legislative majorities").

233. See, e.g., Hatchard v. Westinghouse Broadcasting Co., 532 A.2d 346, 350 (Pa. 1987) (stating that state constitution establishes reputation as "fundamental right[ ]"); Bernzen v. City of Boulder, 525 P.2d 416, 419 (Col. 1974) (stating that state constitution designates recall, initiative, and referendum as "fundamental rights ... which the people have reserved unto themselves"); Pacheco v. School Dist. No. 11, 516 P.2d 629, 633 (Col. 1973) (Kelley, J., dissenting) (stating that state constitution guarantees "fundamental values" against erosion by legislature).

234. Kaye, supra note 5, at 421.

235. See supra notes 19-22 and accompanying text; see also Jerry Frug, Argument as Character, 40 STAN. L. REV. 869 (1988). 
aspects of the character of the people who adopted it, a feature that courts can occasionally exploit in order to assist them in construing the constitution in difficult cases. ${ }^{236}$

In this view, as noted earlier, constitutional discourse transcends the bounds of any particular legal dispute or occasion for judicial action; it becomes instead a forum in which the members of a polity debate their own identity - their character and fundamental values. Under the influence of a robust constitutional discourse, the contours of the constitution thus come to define not merely a body of positive law but the identity and character of the polity itself.

\section{Local Variations in Character}

State constitutionalism, then, holds that a state constitution is the creation of the sovereign people of the state and reflects the fundamental values, and indirectly the character, of that people. An important corollary of this proposition is that the fundamental values and character of the people of the various states actually differ, both from state to state and as between the state and national polities. One can confirm this corollary by simple observation: no two state constitutions are identical, and no state constitution is identical to the federal Constitution. These variations, because they occur in constitutions, are by definition of constitutional dimension; the people who adopted the constitutions could have made them identical but deliberately chose different language and provisions. It follows that these differences reflect differences in the fundamental value choices and character of the people who made the constitutions.

This type of argument appears frequently in New Federalism literature. We are told, for example, that a state constitution must be viewed as "a declaration of certain values held by the citizens of that state" and that the constitution "reflects the geography, history, culture and uniqueness" of the state. ${ }^{237}$ Courts, it is said, have a responsi-

236. Certainly the most notable example of this technique is Ravin v. State, 537 P.2d 494 (Alaska 1975). There, the Alaska Supreme Court held that the right to privacy guaranteed by the state constitution required the invalidation of a law criminalizing the possession of small amounts of marijuana in the home. In reaching this conclusion, the court relied explicitly on what it viewed as the unique character of Alaskans:

The privacy amendment to the Alaska Constitution was intended to give recognition and protection to the home. Such a reading is consonant with the character of life in Alaska. Our territory and now state has traditionally been the home of people who prize their individuality and who have chosen to settle or to continue living here in order to achieve a measure of control over their own lifestyles which is now virtually unattainable in many of our sister states.

537 P.2d at 503-04. The result in Ravin has since been overturned by passage of a ballot measure. See infra note 283.

237. Judith S. Kaye, A Midpoint Perspective on Directions in State Constitutional Law, 1 EMERGing IsSues IN ST. CONST. L. 17, 19 (1988); see also Abrahamson, supra note 29, at 965 
bility "to create for each state a jurisprudence uniquely expressive of that state's own constitutional culture and faithful to its own particular traditions."238 Professor A.E. Dick Howard has summed up this view of state constitutionalism succinctly:

[N]o function of a constitution, especially in the American states, is more important than its use in defining a people's aspirations and fundamental values. ...

... A state constitution is a fit place for the people of a state to record their moral values, their definition of justice, their hopes for the common good. A state constitution defines a way of life. ${ }^{239}$

If the people of the states have unique cultures, traditions, or values - if they have chosen different ways of life - how might these differences translate into constitutional terms? Consider the following comparison:

The founders of a populist frontier state with a tradition of ferocious individualism, like Washington or Oregon, probably intended to carve out a larger sphere of rights, a larger arena of activity into which the government could not intrude, at least with respect to such matters as bearing arms and avoiding scrutiny, than a more communitarian, homogeneous state like Massachusetts or one with sectarian roots like Maryland. Those latter states, on the other hand, might be assumed to have cared more deeply about matters of religion. ${ }^{240}$

This narrative is a powerful one, for it contemplates potentially different meanings even for constitutions containing identical language. These variations in meaning would stem from variations in the character of the polities, character differences that cause them to embrace as fundamental substantially different values - in this case, the untamed but irresponsible westerner and the domesticated but righteous easterner choose different ways of life.

This type of reasoning seems to hold out the greatest hope for the type of independent state constitutional discourse New Federalism aims for, yet it appears virtually nowhere in the actual discourse of state constitutional law. Why? In the following sections I argue that participants in the legal system do not talk this way for the simple

(A state's "land, its industry, its people, its history" may be "peculiarities" that will influence interpretation of the state constitution.).

238. Teachout, supra note 28, at 19; accord NettikSimmons, supra note 203.

239. Howard, supra note 33, at 14; see also Howard, supra note 196, at xxiii; Howard, supra note 25, at 938-39. Other commentators have taken a similar view. See, e.g., Kaye, supra note 237, at 19; Linde, supra note 30, at 395; Teachout, supra note 28, at 19.

240. David Schuman, Advocacy of State Constitutional Law Cases: A Report from the Provinces, 2 EMERGING IsSUES IN ST. CONST. L. 275, 285 (1989); cf. Utter, supra note 35, at 244 (drawing inferences based on "the vast differences in culture, politics, experience, education and economic status between ... the Washington framers of 1889 and the Eastern framers of the United States Bill of Rights in 1789 [sic], and the enormous differences of history and local conditions that separated the two conventions"). 
reason that such talk would make no sense. This is so for three reasons. First, the notion of state constitutions as defining distinctive and coherent ways of life does not accurately describe actual state constitutions and thus cannot furnish a useful way of talking about them. Second, state constitutionalism itself embraces theoretical inconsistencies that impair its usefulness as a framework for state constitutional discourse. Most significantly, state constitutionalism is incompatible with national constitutionalism; indeed, the type of robust state constitutionalism advocated by New Federalism could pose a serious threat to the nationwide stability and sense of community that national constitutionalism provides.

Finally, whatever currency the notion of local variations in character and values might once have had, it is a notion that no longer describes in any realistic way the polities of the present day states. Regardless of what they may once have been, Americans are now a people who are so alike from state to state, and whose identity is so much associated with national values and institutions, that the notion of significant local variations in character and identity is just too implausible to take seriously as the basis for a distinct constitutional discourse.

\section{B. Conundrums of Character}

Suppose we take seriously the premises of federalism and constitutionalism and apply them to the interpretation of state constitutions we must never forget, we might say, that it is a state constitution we are expounding. To undertake this task is to encounter significant contradictions and implausibilities in the doctrine of state constitutionalism.

The average state constitution is about four times as long as the U.S. Constitution; ${ }^{241}$ the constitutions of Alabama, Oklahoma, and Texas are more than eight times as long. ${ }^{242}$ While every state constitution contains a bill of rights and sets out a basic three-branch governmental structure, the additional length of state constitutions is attributable primarily to two factors. First, state constitutions typically cover a much broader scope of subject matter than the federal Constitution. For example, almost every state constitution contains lengthy and explicit provisions about financial matters - how taxes are to be assessed, how revenue bills are to be enacted, how revenues 
are to be collected and spent. ${ }^{243}$ Some state constitutions contain detailed provisions relating to aspects of transportation such as highways, ${ }^{244}$ railroads, ${ }^{245}$ or levee construction and maintenance. ${ }^{246}$ Other constitutions contain provisions dealing with corporations, ${ }^{247}$ mines, ${ }^{248}$ interest rates, ${ }^{249}$ lotteries and bingo, ${ }^{250}$ and prisons. ${ }^{251}$ These are, of course, concerns entirely absent from the U.S. Constitution that are handled on the federal level exclusively as legislative matters.

Second, state constitutions differ from the federal Constitution in the level of detail in which they describe, and therefore the extent to which they constrain, governmental action with respect to subjects covered by the constitution. For example, as Judge Kaye of the New York Court of Appeals is fond of pointing out, ${ }^{252}$ the New York Constitution contains a provision specifying the width of ski trails in the Adirondack Park. ${ }^{253}$ The California Constitution specifies the way in which taxes are to be assessed on golf courses. ${ }^{254}$ The Texas Constitution provides for banks' use of "unmanned teller machines."25s

If a state constitution reflects the character of the people of a state, what can one say about the character of a people who enshrine these types of provisions in their constitutions - who evidently hold the values expressed in these provisions so dear that they see a need to place them beyond the reach of temporary majorities and transient passions, and to permit their alteration only by future direct action of the people themselves? Can one say of New Yorkers, for example, that they are a people who cherish their liberty to ski? If so, how does such a provision fit in with the other liberties contained in the New York Constitution, such as freedom of speech? Are New Yorkers a people who like to talk and schuss? To ski down a mountain and discuss politics over hot chocolate? If we are to take seriously the notion that the state constitution reveals the character of the people, we may be forced to the unappetizing conclusion that the people of New York,

243. See, e.g., CAL. CONST. art. XIII; N.Y. CONST. arts. 7-8.

244. See MinN. Const. art. 14.

245. See, e.g., OKLA. CoNST. art. IX; Mo. Const. art. 11, §§ 9-11.

246. See Miss. ConsT. art. 11.

247. See, e.g., IDAHo CONST. art. 11; Mo. CONST. art. 11; TEX. CONST. art. XII.

248. See, e.g., WY. CoNST. art. 9; N.M. CONST. art. 17.

249. See, e.g., CAL. Const. art. 15.

250. See, e.g., KAN. CoNST. art. 15, §§ 3, 3a.

251. See, e.g., Miss. Const. art. 10.

252. Kaye, supra note 237, at 18-19; Kaye, supra note 5, at 408.

253. See N.Y. CONST. art. $14, \S 1$.

254. See CAL. Const. art. 13, § 10.

255. See TEX. ConsT. art. 16, §16. 
or California, or Texas are simply a frivolous people who are unable to distinguish between things that are truly important and things that are not.

In a similar vein, consider that Louisiana has had eleven constitutions since it became a state, and that Georgia has had nine, South Carolina seven, and Virginia, Alabama, and Florida six each. ${ }^{256}$ The Alabama Constitution has been amended over five hundred times, ${ }^{257}$ the California and South Carolina Constitutions over four hundred times, and the Texas Constitution more than two hundred times. ${ }^{258}$ If these histories also reveal the character of the people of the states, they reveal people who are fickle and unreflective - people who do not know what they want, who change their mind frequently, and who are apparently incapable of learning from their mistakes.

Conclusions such as these strike powerfully at the premises of constitutionalism. A people who are frivolous, or fickle, or unreflective, are a people not worthy of respect. And a people whom we cannot respect are not a people to whom we can comfortably attribute an overall constitutional plan, a meaningful history of purposeful debate, or a coherent political theory - the very factors noticeably absent from state constitutional discourse. Moreover, this suspicion of the people and of their constitution severely constrains the way in which it is possible to talk about the meaning of the constitution. To be sure, we will always have the text of individual provisions, and there may be some sort of legislative history associated with each such provision. But we may feel extremely uncomfortable in these circumstances adding political, ethical, historical, or structural considerations to the state constitutional discourse because we may feel unable to construct a coherent story about the meaning of the constitution that includes these elements. Again, these elements are generally missing from state constitutional discourse, and their absence can make state constitutional interpretation seem like ordinary statutory construction.

An objection might be raised at this point. Perhaps, it might be said, the seemingly frivolous nature of some state constitutional provisions and the frequency with which state constitutions are amended merely suggest that we are looking for the wrong kind of constitutional meaning. Of course it is ludicrous to suggest that a provision governing the width of ski trails reflects a fundamental value of the people of New York. It is far more likely that such a provision is

256. Sturm, supra note 69 , at 75-76.

257. See Ala. Const. (Michie 1991).

258. Sturm, supra note 69 , at 78-79. 
merely the result of a political compromise, perhaps among environmentalists and development interest groups, and it should be treated as such. It is accordingly a mistake to invest the provision with any more portentous meaning.

If such provisions are merely political compromises - and that certainly seems like a plausible explanation - they pose no less a threat to our notions of constitutionalism than does the idea that the people are incompetent. According to the conventions of constitutionalism, a constitution is not supposed to be the outcome of pluralistic political bargaining on matters of everyday concern; that is the role played in our system by statutory law. Rather, constitutionalism assumes that a constitution is the consensual act of a united society; it is viewed as the outcome of a process of deliberation meant to identify matters of fundamental importance to the people and to place those matters in a constitution specifically to protect them from the quotidian predations of pluralistic power struggles. ${ }^{259}$

To the extent that a constitution or a particular provision departs so far from this model that it cannot plausibly be viewed as anything other than the result of pluralistic logrolling, constitutional discourse is correspondingly impoverished. One cannot plausibly claim a meaning rooted in political theory, or justice, or the framers' deliberations on fundamental principles, for a constitutional provision that can only be explained as the result of a political deal among interest groups. Of course, it is not necessarily impossible to create a rich story about a constitutional provision just because it resulted from compromise. Our federal constitutional tradition has done just that by elevating some of the overt compromises appearing in the federal Constitution to near-mythical status, such as the Great Compromise that created popular representation in the House and representation by state in the Senate - a compromise viewed as so historically significant that we have named and capitalized it. ${ }^{260}$ But the basis of legislative representation is still very different from the taxation of golf courses or the width of ski trails, and it somehow seems improbable that a similar myth could emerge about a constitutional provision such as California's or New York's.

Robert Cover once wrote: "No set of legal institutions or prescriptions exists apart from the narratives that locate it and give it meaning.

259. See supra notes $228-36$ and accompanying text.

260. Another compromise prevented regulation of the slave trade until 1808, U.S. CONST. art. I, $\S 9, \mathrm{cl}$. 1. This feature of the Constitution plays a prominent role in the story of the Civil War and the subsequent Reconstruction Amendments. 
For every constitution there is an epic ...."261 Yet state constitutions are hard-pressed to generate epics to give them meaning. When we turn upon state constitutions the narrative devices we use to create constitutional meaning on the federal level, we find state constitutions wanting. The stories to which they lend themselves are not stories of principle and integrity, but stories of expediency and compromise at best, foolishness and inconstancy at worst. And the poverty of state constitutional discourse merely reflects the limited narrative possibilities that state constitutions offer to erstwhile interpreters. ${ }^{262}$

But if this description is accurate, it reveals yet another contradiction. We cannot seriously be willing to accept the conclusion that the people of the states are incapable of competent constitutional self-government. In fact, we know such a proposition to be false because every state citizen is also a citizen of the United States, and therefore, politically speaking, an author of the U.S. Constitution. Yet the U.S. Constitution is not only a vehicle of competent constitutional self-government, but a model emulated throughout the nation and the world. As noted earlier, it is the focus of an extraordinarily rich constitutional discourse - one providing the material for a true epic - that allows U.S. citizens to debate the meaning of the Constitution and, by so doing, to debate their own identity. ${ }^{263}$ By taking seriously the premises of state constitutionalism, we seem driven to the position that the people of the United States are simultaneously both competent and incompetent practitioners of constitutional self-government.

What can explain these contradictions? The next section argues that the divergence between the pedestrian reality of state constitutions and the grand predictions of state constitutionalism can be explained in part by two factors: the incompatibility of state and federal constitutionalism, and American society's choice to adopt a national rather than a state identity.

261. Robert M. Cover, Foreword: Nomos and Narrative, 97 HARv. L. REv. 4, 4 (1983).

262. Even Hans Linde himself, one of the guiding forces behind New Federalism, has recognized this aspect of state constitutional law. State constitutions, he has written, "demystify constitutional law. . . . They have drafters, yes, but no 'Founders'; no Federalist Papers; no equivalence of constitution and nationhood; no singularity[;] . . . no sanctified judges; certainly no claim as a 'civil religion' or as the perfect embodiment of justice, when there are forty-nine others." Linde, supra note 5, at 197 (footnote omitted). Linde goes on to ask why, if a constitution does not enshrine "strongly held values," we ought to respect it. Id. at 198. His answer simply falls back on convention: "Any student of state constitutions knows that some of their provisions deserve very little respect, but they are nonetheless the law ...." Id.

263. See supra notes 19-24 and accompanying text. 


\section{The Incompatibility of State and Federal Constitutionalism}

\section{The Framework of Nationhood}

Certainly one of the foundational and indispensable beliefs of American political and social life is that we are a nation, which is to say that we constitute collectively a certain community. To have a sense of community sufficient to sustain such a belief is to have, as Robert Burt has pointed out, "an acknowledged common identity" capable of transcending disputes and differences that arise among us. ${ }^{264}$ Under what conditions can such a common identity exist? According to James Boyd White, a community is, on the most basic level, "a group of people who tell a shared story in a shared language."265 On this view, discourse is a critical element of the communal relationship: The "community talks itself into an historical identity."266

One way discourse accomplishes this task is by revealing and maintaining the common values of the members of the community. ${ }^{267}$ The existence of such values is a necessary condition for the emergence of a community; as Kenneth Karst has put it, American nationhood rests on a shared culture, national in scope, consisting of, at minimum, "a set of universal norms."268 Moreover, such a community cannot be forced into existence or declared to exist by fiat; ${ }^{269}$ it can arise "only as a by-product of the shared pursuit of more tangible goals and activities." 270

For Americans, discourse, values, and activities all intersect in the U.S. Constitution: it is a text, and thus a form of discourse; its subject matter is the values of society; and it is used in a real way as part of the activity of self-governance. As a result, the Constitution performs a highly important function in not only symbolizing American nationhood, but in constituting it as well. ${ }^{271}$ It serves as a focal point for the creation and perpetuation of a plausible narrative identity for the

264. Robert A. Burt, Constitutional Law and the Teaching of the Parables, 93 YALE L.J. 455, 456 (1984).

265. WhITE, HeRACLES, supra note 14, at 172.

266. Kahn, supra note 20 , at 3.

267. Id.

268. Kenneth L. Karst, Belonging in America 28-31, 31 (1989).

269. See Burt, supra note 264, at 486; cf. Milner S. Ball, Stories of Origin and Constitutional Possibilities, 87 Mich. L. REv. 2280, 2315 (1989) (arguing ideas cannot transform the popular will).

270. KARST, supra note 268, at 180 (quoting DeNNIS H. WRONG, SKEPTICAL SociologY 79 (1976)).

271. KARST, supra note 268, at 177; WHITE, HeRACLES, supra note 14, at 41 ; see also KAMMEN, MACHINE, supra note 17, at 68-94; Note, Amendomania, supra note 26, at 281 (noting that California Constitution is "totally unfit to be a popular ideological rallying point or symbol"). 
national community and its individual members. ${ }^{272}$

But if the Constitution helps create and define a national identity, it also helps to set limits - both for the community and for its individual members - on what that identity can be. ${ }^{273}$ If we as a nation are a community that holds certain values, then it becomes difficult for those who consider themselves to be members of the community to hold different or incompatible values and to act on them. Suppose, for example, that the Constitution embodies "a fundamental value determination of our [national] society that it is far worse to convict an innocent man than to let a guilty man go free."274 If so, society would be extremely hard-pressed to tolerate behavior by individuals or subgroups based on the notion that the goal of pursuing the guilty justifies inadvertently harming the innocent. If we are a people who value jus. tice, one might say, can we also be a people who value expediency?

It is in this sense of constraining identity - what Robert Cover called the "jurispathic" function of law 275 - that the existence in our system of state constitutions is in tension with the premises of national constitutionalism and may even pose a genuine threat to it. Our constitutional language and culture hold the U.S. Constitution to be the repository of the fundamental values of the national community, a community to which every citizen belongs. When we apply the same conventions to state constitutions, we are led of course to the same conclusion: state constitutions are also the repository of fundamental values, but the values are those of the peoples of the individual states.

This arrangement is workable, although seemingly redundant, as long as the state and federal constitutions are congruent. But if they differ, the conventions of constitutionalism compel the conclusion that the values embodied in the state constitution are fundamental to the people of the state but not to the people of the nation, and vice versa. This, too, would be untroubling were it not for the fact that the members of the state community are also members of the national community. Thus, when a state constitution conflicts with the national Constitution, we can only conclude that the people of that state consider certain values fundamental for themselves, but not for the rest of us.

Even on the most basic level, this type of divergence can be unsettling. If a value is good enough to be fundamental to the people of the

272. See Ball, supra note 269 , at $2282-87$ (discussing the American story of national origin).

273. See Kahn, supra note 20, at 5 ("Individual identity does not exist apart from the discourse that creates and sustains the community.").

274. In re Winship, 397 U.S. 358, 372 (1970) (Harlan, J., concurring).

275. Cover, supra note 261, at 41-42. 
state, one might say, why isn't it good enough for everybody? There is something vaguely selfish and hostile about the people of a state going off to their own corner and making up rules for their own self-governance that they think superior to the ones the rest of the country has decided to use. And even were this not the case, it is difficult to accept the idea that fundamental values on which all Americans agree can really differ significantly from place to place. Can the elements of basic human dignity, for example, really mean something very different to the inhabitants of Ohio and Indiana?276

More importantly, though, discrepancies between the state and federal constitutions can also be viewed as unintelligible inconsistencies - the same individuals, it seems, have given two different, and possibly incompatible, accounts of the values they hold fundamental. For example, the national community holds the imposition of cruel punishments to be morally wrong; ${ }^{277}$ this belief defines a people whose character is such that they recoil at the idea of using torture for any purpose, no matter how worthy the goal. Suppose the people of a state adopt a constitution lacking such a provision, or repeal a similar provision in the present state constitution. Can we then say that such a decision reveals a character that is untroubled by the use of torture? Such an inference embraces another contradiction: how can the same person simultaneously have both types of character? Constitutionalism itself rejects such a possibility - if a constitution reflects the character of a people then it cannot simultaneously reflect the opposite of their character. ${ }^{278}$

Furthermore, attempting to salvage the character principle as an explanation for constitutional differences tends to reduce the concept of character to triviality. Consider a fairly common instance in which a state's constitutional law may differ from federal constitutional law or from the constitutional law of other states. Until 1983, the U.S. Supreme Court interpreted the Fourth Amendment to preclude the issuance of a search warrant on the tip of an anonymous informant

276. Cf. Project Report, supra note 25, at 277 ("If a coerced confession was repugnant to human dignity why should it matter which government happened to be exacting it?").

277. See U.S. CoNsT. amend. VIII.

278. A dedicated postmodernist might say that I have done nothing more here than describe the postmodern condition - this is simply how we live our lives, participating in many inconsistent activities and discourses, and that is just the way it is. The postmodern outlook thus deals with such contradictions not by resolving them but by accepting them as inevitable. For an interesting response to this view, see ALASDAIR MAcINTYRE, WhOSE JUSTICE? WHICH RATIONALITY? (1988). In any event, the postmodernist answer does not help here; as a participant in the discourse, a court is obliged to avoid inconsistencies, or at least the appearance of inconsistency. To embrace inconsistency would be to appear to abandon the ideal of the rule of law, an act that could have seriously destabilizing ramifications for society. 
unless the warrant application satisfied a two-part test designed to assess the informant's veracity and the basis of the informant's knowledge - the so-called Aguilar-Spinelli test. ${ }^{279}$ In Illinois v. Gates, ${ }^{280}$ the Court abandoned the two-prong Aguilar-Spinelli test and adopted the so-called "totality of the circumstances" test, a standard more favorable to the state. Inevitably, numerous states were asked to apply parallel provisions of their state constitutions to cases like Gates. Prosecutors of course argued that the state provisions called for the totality of the circumstances test, and defendants argued that the earlier Aguilar-Spinelli standard better captured the state's constitutional standards. Several states reached this issue as a matter of state constitutional law; some adopted the Gates test and others rejected it.281

Leaving to one side the contradictions pointed out above, it is simply implausible that these different constitutional doctrines can be attributed to differences in the fundamental character and values of the people of the states. What possible trait of character could cause someone to prefer a "totality of the circumstances" test for issuing a search warrant to a two-prong informant reliability test? To say that "we are a people who use the totality of the circumstances test" is to speak gibberish; it is like saying "we are a people who eat our stew with a fork instead of a spoon." Such preferences undoubtedly exist, but they cannot plausibly be traced to any fundamental value or character trait.

Of course, on some level every difference in personal preference or behavior must be traceable to some personal trait that differs from the traits of others who behave differently in similar circumstances; if that were not the case then everyone would reason and behave identically. But to call all such variations differences of character would be to reduce the concept of character to triviality: it would account for everything, and thus nothing.

\section{The Dangers of a Robust State Constitutionalism}

At this point, the following objection might be raised. These contradictions and implausibilities are interesting, it might be said, but suppose that the people of a state just do really happen to have a character that differs from the people of other states or of the nation. Sup-

279. See Spinelli v. United States, 393 U.S. 410, $415-19$ (1969); Aguilar v. Texas, 378 U.S. 108, 113-15 (1964).

280. 462 U.S. 213 (1983).

281. Compare State v. Arrington, 319 S.E.2d 254, $260-61$ (N.C. 1984) (adopting Gates) and State v. Walter, 670 P.2d 1354, 1358 (Kan. 1983) (same) with State v. Jackson, 688 P.2d 136, 143 (Wash. 1984) (rejecting Gates) and State v. Kimbro, 496 A.2d 498, 507-08 (Conn. 1985) (same) and Commonwealth v. Upton, 476 N.E.2d 548, 556 (Mass. 1985) (same). 
pose it happens that the inhabitants of a state disagree collectively with enough aspects of the national Constitution, or disagree so vehemently with a single aspect of the Constitution, that these disagreements can only be understood as reflecting actual differences in character between the people of the state and the people of the nation. Wouldn't their constitution, if it embodied these differences, then reflect fundamental differences of character in the way state constitutionalism predicts?

The answer of course is yes, by definition. However, while nothing makes such a development impossible as a factual matter, it would pose a problem of some seriousness and potential danger to the people of the state and of the nation and is thus an inference to be avoided if possible. Suppose, to return to the previous example, that a refusal to embrace the totality of the circumstances test somehow indicated a character fundamentally different from the character that people must possess in order to be members of the national community. If that were the case, then it is possible that the community would have to redefine and reorganize itself, perhaps by casting out the minority who no longer share the dominant national identity. The world stage today is filled with nations that are breaking apart, sometimes violently, apparently due to the perception among subgroups that the national identity is not one in which they can participate - for example, Croats in Yugoslavia, Lithuanians in the former Soviet Union, Tibetans in China, Kurds in Iraq, Tamils in Sri Lanka, Sikhs in India, Quebecois in Canada.

Indeed, the United States itself went through its bloodiest crisis, the Civil War, as the result of just such a domestic conflict over the shape of the national character. One's attitude toward slavery is something that can quite plausibly be viewed, and was viewed, as reflecting a fundamental aspect of character. Once those on each side of the slavery issue came to view those on the other side as having an identity incompatible with their own, the stage was set for secession and war. It can thus be dangerous for the people of a state to say too vehemently and too often, "We are fundamentally different from the rest of the nation." To talk in that way may be to contribute to conditions making it difficult for the state to consider itself, and to remain, a part of the nation. This danger may well account at least in part for state courts' reluctance to make too much of constitutional differences.

\section{The National Focus on Fundamental Values}

If national and state constitutionalism are incompatible - if only one constitution at a time can ever truly and safely reflect the essential 
character and fundamental values of a people - then one form may have to yield to the other. The vigor of federal constitutional discourse and the poverty of state constitutional discourse suggest strongly that this theoretical fault line has shifted in our society, and that national constitutionalism has prevailed over its state cousin. In other words, state constitutional variations simply cannot be understood to reflect local variations in character and fundamental values.

But is this really a justifiable conclusion? Isn't it true that Oregonians have roots in a frontier culture characterized by extreme individualism, and that Massachusetts society has its roots in Puritanism and social homogenization? And aren't such differences properly viewed, notwithstanding any danger, as differences in character? I think not. The tension between state and national constitutionalism has been largely resolved in the modern day United States by the collapse of meaningful state identity and the coalescence of a social consensus that fundamental values in this country will be debated and resolved on a national level. Thus, regardless of whether such regional differences existed in the past, they no longer exist and we may for the most part disregard them as viable elements of state constitutional discourse.

First, in the modern world, any serious variations in the character of the people of individual states must have an extremely short halflife. The national Constitution guarantees a right to travel among the several states, ${ }^{282}$ and the ease of mobility and the national structure of the economy all but guarantee quick dilution of any truly significant local traits. ${ }^{283}$ Indeed, with the help of modern communications technology such dilution can occur without anyone traveling at all. We all watch the same national news and the same prime-time television shows; we listen to the same music on the radio; we shop in malls with the same stores; we eat at the same chain restaurants. It is difficult to see how any truly fundamental character differences could stand up against such a cultural assault.

Some might object that these recent developments are irrelevant to

282. Shapiro v. Thompson, 394 U.S. 618, 629 (1969).

283. Cf. Pollock, supra note 35 , at 986 (arguing that the national economy and mobility reduce attention to distinct local traits). Perhaps the most dramatic example of this phenomenon is the popular overturning in Alaska of Ravin v. State, 537 P.2d 494 (Alaska 1975). In that case, the court relied on the "individuality" and desire for "control over their own lifestyles" of Alaskans to strike down a law criminalizing marijuana possession on state constitutional grounds. 537 P.2d at 504. Fifteen years later, the people of the state overturned this decision by ballot initiative. The 1990 Elections: State by State, N.Y. Times, Nov. 8, 1990, at B8, B9; see also Richard Maver, Alaskans to Vote on Marijuana Use, N.Y. TIMES, Oct. 25, 1990, at A17, col. 1. This suggests that the Alaskan character of rugged individualism did not hold out for long against the nationwide hardening in attitudes against drug use. 
the interpretation of state constitutions that predate such social changes. But even if one were inclined to accept the argument that contemporary attitudes are completely irrelevant to constitutional interpretation, ${ }^{284}$ a view held in its strict form by virtually no one, ${ }^{285}$ the objection is still unavailing. Most states have adopted their current constitutions, or so significantly amended them, in comparatively recent times that it is difficult to argue that the constitutions cannot be read to incorporate attitudes toward nation and state of relatively recent vintage.

Moreover, $I$ think it is fair to say that at this stage in our national life, Americans tend to focus on and debate issues concerning fundamental values primarily on a national level. ${ }^{286}$ In a recent poll, over half of those surveyed did not even know that their state had its own constitution. ${ }^{287}$ It is difficult to debate an identity expressed in a constitution you do not know exists. Further, national interest and advocacy groups seem to set the agenda of ethical and political issues that people consider fundamental, and to dominate the ensuing debate. And the national reach of even local media allows people to debate these issues with opponents from all parts of the country, not merely from their own state. The abortion debate illustrates this nicely. A great many people, even some who are well informed, labor under the misconception that if the Supreme Court overrules Roe v. Wade, abortion will be illegal; it does not even occur to them that such a ruling would only shift the debate to state forums.

So accustomed have Americans become to debating fundamental moral and policy issues on a national level that, paradoxically, state involvement in such issues can sometimes seem vaguely antidemocratic. For example, you become active in a national issue group, attend rallies, write your congressional representatives, and otherwise slug it out with your opponents. Suppose your side wins. The democratic system has worked, and according to the rules of the

284. Two leading exponents of this view are Raoul Berger and Robert Bork. See Raoul Berger, Government By JUdiciary (1977); Robert Bork, Neutral Principles and Some First Amendment Problems, 47 IND. L.J. 1 (1971).

285. Judge Vito Titone of the New York Court of Appeals has argued that a noninterpretive method of constitutional interpretation is more appropriate for state constitutions than for the federal Constitution because of the recency and ease of amendment of state documents. Titone, supra note 215 , at 471 .

286. See Spaeth, supra note 31, at 736 ("[W] hen we think of our natural rights . . we think of rights protected by the federal Constitution, not by the constitution of the state where we happen to live."); Teachout, supra note 28, at 14 ("For most of our history the constitutional law that has been most important in shaping our culture has been a national constitutional law.").

287. Robert F. Williams \& Earl M. Maltz, Introduction, 20 RUTGERS L.J. 877, 878 n.4 (1989) (citing John Kincaid, State Court Protections of Individual Rights Under State Constitutions: The New Judicial Federalism, 61 J. State Govt. 163, 169 (Sept./Oct. 1988)). 
game your opponents must take their lumps and abide by the decision of the majority - the issue is settled. But when the state chapter of your group starts sending you urgent notices that your position is under attack on the state level, you may well feel betrayed; this battle has been won, and the other side should just go away. Trying to slide something by on the state level seems like poor sportsmanship, if not some kind of political dirty trick.

Corresponding to the national focus of the debate on values is the general absence of public identification with the polity defined by the state. We have no trappings, no rituals, no conventions that could serve even to keep the state in our thoughts. How many people, for instance, own a state flag, or even know what it looks like? How often do governors make televised addresses to the people of the state? As Professor Karst has pointed out, "Before the small-town basketball game begins, the high school band plays 'The Star-Spangled Banner." "288

\section{The Nature of State Constitutional Differences}

We have seen that attributing differences among the various state and federal constitutions to variations in the character of the relevant polities is contradictory, counterfactual, and potentially dangerous. Yet state constitutions do differ, and those differences can have significant legal effects. If constitutional differences do not result from local variations in the character and values of the people, how can we account for them and what interpretation should we give them? The answer, I suggest, lies in treating character itself as a more complex phenomenon than proponents of New Federalism are wont to do.

Consider our notion of dissent. Many constitutional decisions of the U.S. Supreme Court are not unanimous; different Justices have different views about how the Constitution applies in particular circumstances, which occasionally leads them to dissent. Yet we do not consider a divided Supreme Court opinion to impugn in the least our belief in the reality of our nationhood, nor do we attribute such differences in opinion among the Justices to particularized personal attributes that rise to the level of ontological significance. Indeed, to attribute a dissent to a truly fundamental difference of character between the dissenters and the majority would be to question the extent to which the dissenters can really be a part of the national community - it would be, in essence, to question whether they are real Americans. Of course, questioning the Americanism of those with whom we 
disagree is unfortunately an all too commonly employed rhetorical device. But responsible people avoid such accusations because of the danger they pose to the stability and coherence of the national community - we have no real wish to become a people who cast out those who disagree with the majority.

The idea of dissenting opinions furnishes a useful model for thinking about state constitutional variations. A dissenter in a constitutional case is one who disagrees with the majority about the meaning of the constitution, yet is nonetheless someone we can still consider to be a member of society - someone who shares our fundamental sense of identity and the values that help constitute that identity. ${ }^{289}$ That dissenters can exist within a society without significantly disrupting it reveals an important aspect of communal identity: a community is not composed of uniform individuals who share every attitude and value. Rather, society is textured in an irregular, clumpy way; some people embrace society's dominant values more firmly than others, or embrace certain values and not others, or hold idiosyncratic views about what behavior society's values require in certain situations. Yet all these people may nevertheless share essentially in the communal identity.

Of course, there are limits to how far any individual can wander from the mean and still be a person capable of sharing in the communal identity. Those who roam beyond the tolerable boundaries of communal identity might be people so fundamentally different from the members of the community that we may justly describe them as having a different character. But it seems clear that the character of a workable national community must be sufficiently broad to embrace a great deal of individual variation.

This notion of clumpy, irregular variations of a single national character offers a better model of state-to-state differences in the populace than does the notion of fundamental character variations from subgroup to subgroup. Taken together, the views of all members of the national community yield a certain national profile. But because of the irregularity of variations from the national mean, the views of any given subgroup of the community, such as the people of a state, might yield a profile somewhat different from the national one. This does not mean, however, that the people of the state possess a different character from the people of the nation; it means only that they pos-

289. See Burt, supra note 264 , at 456 (stating that adjudication in a democracy depends on "an acknowledged common identity that transcends the divisive implications of the immediate dispute"). 
sess the various elements of the national character in slightly different proportions than does the nation as a whole.

On this view, differences among state constitutions and between the federal and state constitutions do not reflect the fundamentally distinct choices of fundamentally distinct groups; rather, they reflect the varied outcomes of constitutional bargaining among essentially similar subgroups distributed in slightly different proportions within each state. That is, the subsets of the populace defined by the states, when given the opportunity to draft their own constitutions, come up with documents that differ from the national one to the same extent that views represented on the national level are represented in different proportions within the state. Of course, to take this view is to reject state constitutionalism as New Federalism conceives it; as explained earlier, the idea that state constitutions result from political bargaining and opportunism rather than deliberation and choice is an idea that conflicts with the premises of constitutionalism.

\section{Some Possible Resolutions}

If the assumptions and predictions of state constitutionalism do not mesh with the realities of national identity, is there any way to resolve this tension? How, in other words, should we treat state constitutions if the assumptions of constitutionalism do not adequately describe them? In this Part, I touch briefly on three possible ways out of the current impasse.

The first solution, and the one most consistent with the tenets of New Federalism, would be to revise state constitutions to make them the reflections of the fundamental values and character of the state polities that constitutionalism says they ought to be - to conform reality to theory. This would be a task of monumental proportions and probably quite impossible. It would require at a minimum the wholesale amendment of state constitutions to eliminate frivolous, overtly political, and excessively technical provisions that undermine the sense of seriousness that state constitutions convey. But even more, it would require a widespread reorientation of attitudes toward the state. It seems highly unlikely that state constitutions could plausibly be refashioned into true reflections of the character of the people of the state so long as the people continue to identify so little with the community that the state polity theoretically defines.

The only way out of this dilemma is to convince the people of the states that they really do constitute unique communities that differ in fundamental ways from the communities defined by neighboring states and by the nation. But it is doubtful that such an effort could succeed 
at this point. Americans' identities have drifted so far from association with the states and are so closely woven into a national identity that the trend seems all but irreversible. Moreover, it is not at all clear that reorienting attitudes in this way would be ultimately beneficial. Convincing the people of the states that they constitute unique communities means convincing them that they differ from one another in significant ways. But convincing them that they are different makes them so - such a belief takes on a reality by its own force. Unfortunately, fostering the cleavage of society in this way threatens the stability of the national community: if the people of a state embrace an identity that makes them different from the national community, they may view themselves as too different to remain part of the national community. As I suggested earlier, this path is potentially dangerous, and the threat to national stability posed by stressing differences at the expense of unity seems to counsel against such an approach to state constitutionalism.

If conforming reality to theory proves unworkable, a second approach might be to conform theory to reality by abandoning the strongest claims of state constitutionalism and recognizing that state constitutions simply do not and perhaps cannot reflect the fundamental values and character of distinct state polities. Such an approach might require, for example, that a state constitution be treated as a unique type of document without analogue in our universe of legal documents; a state constitution might thus be viewed as something less than a "real" constitution such as the U.S. Constitution, but something more than a statute. Perhaps state constitutional provisions might be viewed, like statutes, as outcomes of frankly pluralistic power struggles, but concerning subjects that the polity wants for some reason to remove from the political agenda for some period of time. Indeed, this seems to be the direction in which state supreme courts have moved; they are generally unwilling to invoke the grandest interpretive strategies of constitutionalism, but are nevertheless forced to treat constitutional positive law as somehow different from ordinary statutory law. This waffling helps account for the unsettled and unsettling status of state constitutional discourse.

The problem with such an approach, however, lies in justifying its place in a legal system dominated by the conventions of constitutionalism. We seem to lack conventions capable of explaining convincingly why state constitutions serve any particularly valuable function. Why, for example, would the people of a state want to elevate some political decision to constitutional status, thereby placing it beyond the easy reach of the legislature to alter, if the decision expressed in the provi- 
sion is not one that the members of the polity consider particularly fundamental? Seen from the perspective of the conventions of constitutionalism, such a decision seems odd and perhaps inexplicable. These conventions tell us, for example, that fundamental things belong in a constitution and everything else should be a matter of statutory law. There is nothing wrong with resolving highly important social issues by statute, nor is a legislature ever forced to tinker with a political compromise worked out in statutory form. The only reason a legislature might want to disturb a politically sensitive compromise would be some felt need to adjust it; and the materialization of such a need would only validate the initial decision to deal with the matter by statute, since the original solution could be easily reformulated by subsequent legislation rather than by constitutional amendment. Indeed, the conventions of constitutionalism can make this type of state constitutional law seem downright antidemocratic - a constitutional amendment becomes a cheap trick pulled by the legislative majority to elevate a temporary political victory to semipermanent status. ${ }^{290}$

What this discussion shows, I think, is that we currently lack a set of conventions justifying an intermediate place for state constitutional law and guiding us in its use and interpretation. If we are to clarify the role of state constitutions enough to make them useful, we need to develop such conventions. It is quite possible, moreover, that no such conventions can be developed without amending the political theories of federalism and constitutionalism from which the extant conventions are derived. This in turn raises the possibility that the development of new conventions for the interpretation of state constitutions might threaten the conventions governing national constitutionalism. Routinely treating state constitutions as reflecting anything less than the fundamental values and character of the people of the state could gradually erode the respect - some say reverence - for constitutions that underlies the significant place of the federal Constitution in our political system. ${ }^{291}$ The threat of such loss of respect may well be what prevents state supreme courts from frankly abandoning the view that state constitutions express fundamental values, ${ }^{292}$ and leaves them floundering in the no-man's land of current state constitutional discourse.

290. See Williams, supra note 34 , at 175 (questioning whether state constitutions are "expressions of what is thought to be the best structure of government and statement of people's rights," or "instruments of lawmaking through which interest groups ... seek the grand prize of lawmaking, striving to achieve constitutional status for the policy they advocate").

291. See, eg., Lawrence M. Friedman, State Constitutions in Historical Perspective, 496 ANNALS 33, 35 (1988); KAMMEN, MACHINE, supra note 17; Linde, supra note 5, at 197.

292. See supra note 233 and accompanying text. 
A final way to resolve the conflicts between the theory and practice of state constitutionalism is sufficiently radical that I will offer it here not as a serious proposal, but as a guidepost against which other solutions can be judged. The resolution is this: if Americans really do not identify in any meaningful way with their state polities, perhaps the concept of statehood has outlived its usefulness and should be abolished. We might therefore restructure our political institutions to correspond to the communities with which we actually identify. With what communities do we identify? Clearly Americans identify strongly with a national community, and a vital role remains for a constitution national in scope.

But what about identity on a more local level? While I believe that few Americans identify themselves with a community purporting to embrace an entire state, I think that most Americans identify themselves rather strongly with a community embracing their hometown and the immediately surrounding area. The thought "we are a people who ..." seems to have far greater currency when applied to the people of a local community or county than to the people of a state; it seems more plausible to claim that the people of a major metropolitan center have a different character from and hold different values than the people of a rural farming community, even when both communities are in the same state. Yet localities in our system have political control over comparatively few aspects of daily life. ${ }^{293}$

Perhaps what needs to be done is to greatly reduce the role of the states in our political life by redistributing the bulk of state powers between the national government and some level of local government, such as the municipal or county level. This could potentially maintain the significant degree of local control over political decisions that state government offers, while at the same time adjusting the level at which political power is exercised to correspond to the communities with which ordinary people actually identify.

Of course, the actual distribution of powers between national and local government might make a tremendous difference in the workability of such a plan. In addition, it is always possible that a new variety of county or local constitutionalism could lead to a degree of balkanization even less compatible with nationhood than whatever threat a revitalized state constitutionalism might pose. On the other hand, such a redistribution, if it worked, could offer substantial social benefits; perhaps, for example, citizen participation in the political life of the community might increase if citizens identified more readily and 
personally with the government making the decisions that affected them.

\section{CONCLUSION}

Oscar Wilde once wrote: "There is only one thing in the world worse than being talked about, and that is not being talked about."294 Wilde's observation has proved true for state constitutions - they are generally not talked about, but even when they are talked about the talk is usually garbled or unintelligible. I have argued in this article that the silence and uneasy confusion surrounding state constitutions results from our lack of a language in which to speak about them, our lack of a language in which we can comprehensibly debate their meaning.

This is indeed a strange state of affairs. State constitutions seem like important artifacts of our legal system; they are uniformly viewed by participants in the legal system as authoritative sources of positive law that state governmental actors must unfailingly obey. How is it possible that we could lack a useful language in which to speak about such a prominent feature of the legal landscape? The truth, I suggest, is that this question is based on false premises.

People develop the languages they need to develop. They do so when they require a language to help them accomplish some purpose or goal they have set for themselves. When speaking a language fails to accomplish a purpose thought to be worth accomplishing, there is no need to speak it and the language will either disappear or will fail to emerge in the first place. The absence of a language suitable for debating the meaning of state constitutions - a state constitutional discourse - thus suggests that society has no particular need for such a language; debating the meaning of a state constitution is not thought to be an activity particularly worth pursuing. How can this be?

We understand a constitution to be a document that defines a community by identifying its members and by setting out many of their fundamental choices about the way they want to live their lives. A language that allows members of a community to debate the meaning of their constitution allows them to debate their own choices and values, and ultimately their own identity. For a community to lack a language in which to debate the meaning of its constitution can therefore mean only one of two things: either the community has no need to debate its identity, or the community that the constitution supposedly defines does not really exist. Human nature itself precludes the 
first possibility; if discourse creates identity, then no community could exist for long without developing a need for a language in which to debate the nature of its identity. ${ }^{295}$ That leaves the second possibility - the communities in theory defined by state constitutions simply do not exist, and debating the meaning of a state constitution does not involve defining an identity that any group would recognize as its own.

I have argued that this is indeed the case. Americans have a communal identity, but it is a national and not a state identity. We debate our fundamental values and our identity through constitutional discourse, but we do so on a national level, as a national community. Residency in one state rather than another is not viewed as an aspect of individual or group identity, or if it is, it has come to represent aspects of identity that are not bound up with the types of decisions that make us who we are in any kind of essential way. As long as this continues to be the case, state constitutional law is likely to remain marginal to legal life, and future battles over the nature of the American character and communal identity will have to be fought, like their predecessors, on a national level in the forum of federal constitutional law.

295. See WhITE, HeracLES, supra note 14, at 140 ("[T]elling stories about the world and claiming meanings for them" is "as universal and deeply rooted in human nature" as any "intellectual activity" can be.). 